\section{Estudo \\ CoDebate}

em Testão

Dlanejamento
Revista Estudo \& Debate, Lajeado, v. 27, n. 1, 2020. ISSN 1983-036X

DOI: http://dx.doi.org/10.22410/issn.1983-036X.v27ila2020.2483

\title{
CARACTERÍSTICAS SOCIOESPACIAIS DE ÁREA DE INTERESSE SOCIAL DA CIDADE DE SÁO MIGUEL/RN
}

\author{
Daniela de Freitas Lima ${ }^{1}$, Almir Mariano de Sousa Junior ${ }^{2}$
}

\begin{abstract}
Resumo: O crescimento acelerado e desordenado das cidades brasileiras a partir do século XX instaurou problemas de ordem urbana, tais como a irregularidade fundiária, que resulta em prejuízos de ordem social, urbanística, ambiental e jurídica, em especial para áreas ocupadas pela população de menor renda. Este artigo tem a finalidade de analisar as características socioespaciais do Núcleo Urbano de Interesse Social Nossa Senhora de Guadalupe, regularizado fundiariamente no ano de 2018, de modo a discutir as particularidades de áreas deste tipo. Para tanto, foi realizado o acompanhamento das atividades e acessado o banco de dados produzido pelo Programa Acesso à Terra Urbanizada entre os anos de 2015 e 2018; efetivadas visitas in loco; executadas entrevistas com moradores do Nossa Senhora de Guadalupe; comparadas as peculiaridades do núcleo em debate com o Núcleo Tôta Barbosa. Verificou-se que o Núcleo Urbano Nossa Senhora de Guadalupe apresenta heterogeneidade e falta de padrão na formação de quadras; a infraestrutura básica contempla fragilidades de escoamento das águas pluviais, abastecimento de água potável e esgotamento sanitário; em se tratando de renda, esta área apresenta maior vulnerabilidade de rendimento do que os assentamentos subnormais a nível nacional, os índices municipais e o Núcleo Tôta Barbosa. Logo, contata-se que áreas constituídas de forma irregular e com ocupação da populaçáo de baixa renda possuem características que as deixam à margem do efetivo direito à cidade, que pode ser melhorado a partir da legalização das terras e de programas associados a melhorias habitacionais e assistência social.
\end{abstract}

Palavras-chave: Regularizaçáo fundiária; Planejamento urbano; Ordenamento territorial; Venerabilidade socioespacial.

\section{SOCIO-SPATIAL CHARACTERISTICS OF AREA OF SOCIAL INTEREST OF THE CITY OF SÁO MIGUEL/RN}

\begin{abstract}
The accelerated and disorderly growth of Brazilian cities from the twentieth century introduced problems of an urban order, such as land tenure irregularity, which results in social, urban, environmental and legal losses, especially for areas occupied by the low-income population. This article aims to analyze the sociospatial characteristics of the Urban Nucleus of Social Interest Nossa Senhora de Guadalupe, regularized land in 2018, in order to discuss the particularities of areas of this type. To this end, the activities were monitored
\end{abstract}

1 Doutoranda em Engenharia Civil e Ambiental pela Universidade Federal de Campina Grande (UFCG).

2 Professor da Universidade Federal Rural do Semi-Árido (UFERSA), Doutor em Ciência e Engenharia de Petróleo pela Universidade Federal do Rio Grande do Norte (UFRN). 
and the database produced by the Programa Acesso à Terra Urbanizada between the years 2015 and 2018 was accessed; on-the-spot visits; interviews were carried out with residents of Nossa Senhora de Guadalupe; compared the peculiarities of the nucleus under discussion with the Nucleus Tôta Barbosa. It was found that the Nossa Senhora de Guadalupe Urban Nucleus presents heterogeneity and lack of standard in the formation of blocks; the basic infrastructure includes weaknesses in rainwater runoff, drinking water supply and sewage; when it comes to income, this area presents greater income vulnerability than the subnormal settlements at national level, the municipal indexes and the Urban Nucleus Tôta Barbosa. Therefore, it is noted that areas constituted irregularly and occupied by the low-income population have characteristics that leave them on the margins of the effective right to the city, which can be improved by legalizing land and programs associated with housing improvements and social assistance.

Keywords: Land regularization; Urban planning; Land use planning; Socio-spatial Vulnerability.

\section{Introduçáo}

O panorama urbano-rural do Brasil foi modificado mais significativamente a partir do século XX, em decorrência das mudanças capitalistas, sem que houvesse planejamento para que as cidades recebessem as mudanças, o que incidiu em disparidades em seu território. A intensa migração campo-cidade a partir de 1930 foi incentivada pelas mudanças políticas ocorridas na época, como a regulamentação do trabalho (não extensiva ao campo) estímulo da industrialização, construção da infraestrutura industrial, que resultaram a instauração da segregação espacial ou ambiental nas últimas décadas do século, e com a frustação das oportunidades que eram almejadas nas primeiras (MARICATO, 2003).

O surgimento das grandes cidades e a urbanização acelerada incidiram na dominação do campo pela cidade, transformando o campesinato a uma classe subalterna, além de elaborarem populaçóes dispersas e sistemas descentralizados de direitos de propriedade em massivas concentrações de poder político e econômico através da concentração de forças produtivas e força de trabalho no espaço (HARVEY, 2005).

A irregularidade fundiária, elemento de ênfase deste trabalho, configura um dos elementos presentes nas cidades em escala global que potencializa as desigualdades, e é um tema de relevância para discussão. Fernandes (2011) expóe que a maioria que ocupa assentamentos informais são, de fato, pobres e a maior parte dos indicadores socioeconômicos são precários - alfabetização, educação, saúde, mortalidade, renda e emprego.

Ressalta-se que estudos sobre cidades metropolitanas são evidentes, porém, as cidades interioranas carecem de pesquisas que retratem o espaço urbano. Nesta perspectiva, citamos a cidade de São Miguel, localizada no interior do Estado do Rio Grande do Norte, de pequeno porte ao considerarmos o quesito população, que exerce influência sobre outros municípios e que também abriga a problemática de irregularidade fundiária, confirmando a importância da realização de um estudo que a aborde.

Dados da Pesquisa Regiões de Influência das Cidades (REGIC), que apresentam a hierarquia das cidades de acordo com suas centralidades, dos anos de 1972, 1987 e 2007 mostram que em 1972 São Miguel/RN influenciava a cidade de Coronel João Pessoa/RN; em 1987 exercia influência sobre as cidades de Coronel João Pessoa/RN e Pereiro/CE; em 2007 polarizava as cidades de Coronel João Pessoa/RN e Venha-Ver/RN. Além disso, Silva e Bezerra (2018) expressam que pessoas de cidades circunvizinhas se deslocam diariamente 
para São Miguel/RN em busca de comércio e serviços, o que ratifica sua relevância na Região.

Este artigo objetiva analisar as características socioespaciais do Núcleo Urbano de Interesse Social Nossa Senhora de Guadalupe, Sáo Miguel/RN, de modo a discutir as particularidades de áreas deste tipo. Esse Núcleo tinha dominialidade municipal até o ano de 2018 e que foi submetido à Regularização Fundiária de Interesse Social por meio do Programa Acesso à Terra Urbanizada (parceria do extinto Ministério das Cidades e Universidade Federal Rural do Semi-Árido - UFERSA).

Além da introdução, o texto está organizado nas seçōes: dinâmicas da irregularidade fundiária, em que se discorre sobre a informalidade fundiária e seus desdobramentos; metodologia; características socioespaciais do núcleo urbano Nossa Senhora de Guadalupe, em que são elencados os aspectos territoriais e sociais que compóem esta área urbana; consideraçóes finais e agradecimentos.

\section{Dinâmicas da Irregularidade Fundiária}

A presença de irregularidade fundiária é uma problemática a nível global, que acomete especialmente a população mais vulnerável. Conforme expóe Declaração Temática de Assentamentos Informais da Conferência das Naçóes Unidas sobre Habitação e Desenvolvimento Urbano Sustentável (Habitat III), do Programa das Naçóes Unidas para os Assentamentos Humanos (ONU-Habitat, 2016), aproximadamente um milhão de pessoas habitam favelas, número que, de acordo com a entidade, está diretamente ligado à pobreza, à desigualdade e ao mercado de terras excludente.

No Brasil, as cidades, em todas as escalas, abrigam a irregularidade fundiária urbana, que é decorrente do seu processo constitutivo urbano, uma vez que conforme afirma o Ministério das Cidades (2009), na obra Regularização Fundiária Urbana no Brasil, quando tema é propriedade da terra e regularização fundiária, o paradoxo legalidade e ilegalidade remonta à formação do Estado e do território brasileiro.

O intenso processo migratório campo-cidade, que configura uma reversão demográfica do Brasil de $10 \%$ da população urbana no final do século XIX para aproximadamente $80 \%$ no final do século $\mathrm{XX}$, mostra que grande massa que se instalou nas cidades de forma autônoma, o que implica-se em poder dizer que a ocupação ilegal de terras brasileiras é parte intrínseca desse processo (MARICATO, 2003).

Relatório Brasileiro para a Habitat III (IPEA, 2016) discorre que a precariedade habitacional brasileira é decorrente da insuficiência da oferta de soluçóes habitacionais para a população de baixa renda, do alto custo da terra urbanizada e do baixo poderio das famílias. A associação desses elementos resultou na informalidade de moradias em área irregulares fundiária e/ou urbanisticamente, fragilizadas em infraestrutura, serviços e muitas vezes ambientalmente, instaladas, em grande parte, em áreas periféricas e sem interesse do mercado imobiliário.

A atração urbana gerada especialmente a partir da industrialização não teve tempo para planejar a recepção da massa populacional em grande escala que chegaria às cidades brasileiras, resultando em impactos danosos que afetaram com maior significância as 
camadas populares. Essas pessoas não tiveram suas expectativas de melhor qualidade de vida atendidas e, por conseguinte, não detiveram condições financeiras para se estabelecerem em locais com infraestrutura ideal para o desenvolvimento das condiçóes de salubridade.

Uma das alternativas, foi ocupar áreas de risco, de proteção permanente, sem propriedade garantida, o que culminou na irregularidade fundiária, um dos principais problemas acarretados pelo processo formativo das cidades, que causa insegurança à moradia. Sem um título que garanta a propriedade, a população que habita ambientes irregulares está sujeita a desapropriaçóes; as possibilidades de infraestrutura adequada são reduzidas, já que essa não está inserida no contexto formal da cidade, impossibilitando planejamentos que destinem recursos para melhoria urbana; há o impedimento ao acesso ao crédito imobiliário; além da ampliação dos riscos de desmoronamentos nas localidades que deveriam ser resguardadas e ascensão de doenças decorrentes da ausência de serviços básicos. Associa-se à irregularidade, a desatualização cadastral dos municípios e o registro incorreto dos lotes (com área maior ou menor do que a real), que implica em outros problemas como a cobrança indevida de impostos, invasão de áreas ou redução formal da extensão ocupada.

Todo o conjunto, resulta na vulnerabilidade socioespacial, definida por Penna e Ferreira (2014) como um risco social, caracterizada pela concentração da precariedade (ou falta) de serviços coletivos e de investimentos públicos em infraestrutura, que causam prejuízos às comunidades mais pobres; é o processo de interação das condições do território e da população que nele habita.

Destaca-se que a irregularidade, apesar de apresentar impactos e números mais expressivos para a população com padróes de renda mais baixos, também está presente em ambientes ocupados pelo grupo social de renda média alta. Mas, de acordo com Dias et al. (2014), o que diferencia as áreas irregulares com e sem valorização econômica são interesses de cada grupo. Para os autores, enquanto os grupos sociais mais vulneráveis ocupam essas localidades por poder aquisitivo limitado, as áreas centrais estão neste quadro por interesses especulativos. Além disso, segundo esses pesquisadores, o acesso à regularização posterior à ocupação é facilitada aos ambientes com alto valor monetário em detrimento daqueles sem valorização, uma vez que há a influência política, cartorária e judiciária pelos seus "proprietários".

Para Ministério das Cidades (2014), através de análise do censo demográfico de 2010 da pesquisa sobre características urbanísticas do entorno dos domicílios, o quantitativo de domicílios urbanos irregulares no Brasil é de aproximadamente 18 milhóes, o equivalente a $31,7 \%$ do total, sendo 12 milhóes destes ocupados por famílias com renda per capita de até um salário mínimo. Esse número foi estimado considerando-se domicílios com logradouros não identificados.

A ilegalidade das ocupaçóes está presente em todos os países e alcança maiores proporçôes em Estados com ampla desigualdade socioeconômica, como é o caso do Brasil, o que resulta em diversos impactos de fragilidade social, dentre os quais estão a baixa qualidade de vida dos moradores, deficiência do acesso aos serviços e bens públicos e privados relevantes, insegurança à propriedade e à posse, acentuação dos impactos ambientais (REIS; OLIVEIRA, 2017). 
O IBGE (2013) apresenta estudo sobre aglomerados subnormais, que são conceituados por este instituto como conjunto constituído por 51 ou mais unidades habitacionais carentes, que possuem precariedade dos padrôes de urbanização e serviços públicos essenciais e inserem-se nas categorias de: invasão, loteamento irregular ou clandestino, e áreas invadidas e loteamentos irregulares e clandestinos regularizados em período recente. Pode ser composto por um ou mais setores censitários, que são pequenos recortes territoriais que servem para organizar e gerenciar a coleta de informações. Sua identificação é feita com base na ocupação ilegal da terra, urbanização fora dos padróes vigentes, precariedade de serviços públicos essenciais (energia elétrica, lixo, redes de água e esgoto).

De acordo com o IBGE (2013), existe 6.329 aglomerados subnormais no Brasil, o equivalente a aproximadamente $5 \%$ do total de setores censitários utilizados para coleta de dados deste órgão (15.868, dos 317.000 setores censitários, são aglomerados subnormais), contabilizando em sua extensão 3.224.529 domicílios particulares permanentes ocupados.

A ONU-Habitat (2016) expressa que os assentamentos informais são resultantes da inter-relação do "crescimento populacional e migração rural para urbana; da pobreza; de déficits de serviços básicos; da precariedade em estruturas e políticas de governança; do acesso limitado a mercados financeiros, terrenos e propriedades".

Neste sentido, Fernandes (2011) afirma que as habitaçōes em assentamentos informais geram para seus residentes a insegurança da posse, a falta de serviços públicos, a discriminaçáo por terceiros, perigos ambientais e para a saúde, e desigualdade de direitos civis. Além disso, o autor afirma que essa informalidade é decorrente de vários motivos: baixos níveis de renda, planejamento urbano impraticável, falta de terrenos com fornecimento de serviços de rede pública e habitaçóes de cunho social e sistema jurídico falho.

Ratificando o que aponta Fernandes (2011) sobre as características socioeconômicas e espaciais da população habitante em localidades irregulares, o IBGE (2013) traz no estudo sobre aglomerados subnormais do Censo de 2010, indicadores que mostram a vulnerabilidade dos moradores dessas áreas. O percentual de $47,5 \%$ de todos os domicílios do País em aglomerados subnormais estavam em áreas predominantemente de aclive moderado ou acentuado, dos quais as regióes Nordeste e Sudeste detêm as maiores proporçóes de domicílios em áreas predominantemente de aclive acentuado, cada uma com $25 \%$ do total. Revela-se que as construçóes com mais de um pavimento, sem espaçamento e com baixo arruamento são predominantes nas áreas com aclives ou declives acentuados ou moderados, enquanto as construções de um pavimento, com quadras bem definidas e com vias que permitem o traslado de carros e caminhóes são mais presentes nas áreas planas. A Figura 1 mostra o percentual de domicílios particulares ocupados em setores censitários de aglomerados subnormais, por espaçamento predominante entre as construçóes, segundo as Grandes Regiōes - 2010. 
Figura 1 - Domicílios particulares em aglomerados subnormais por espaçamento predominante entre as construçóes.

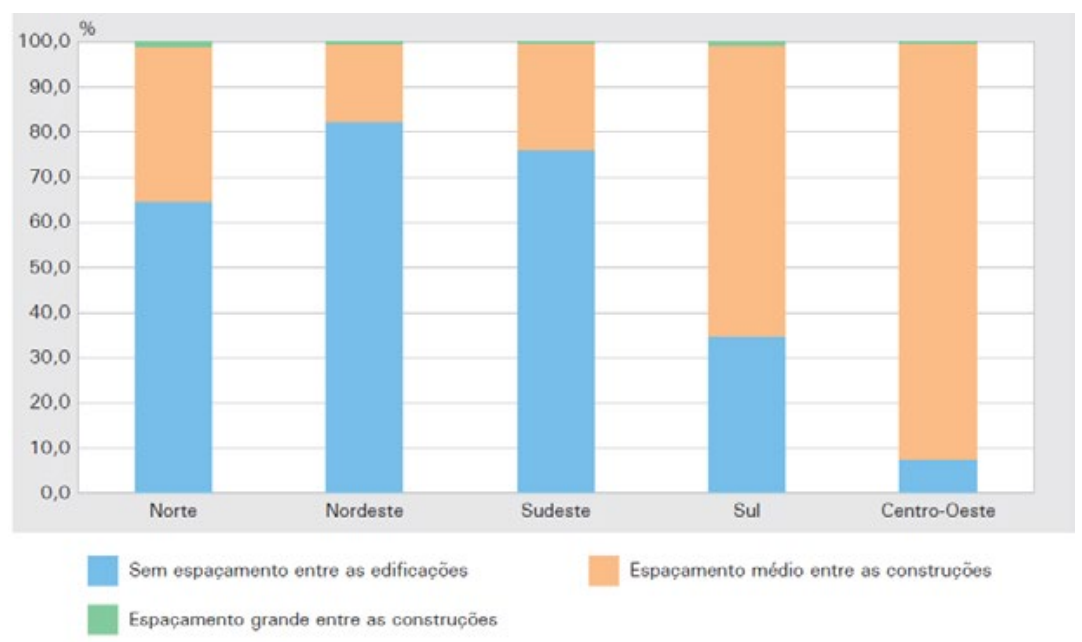

Fonte: IBGE, 2013, Censo Demográfico 2010.

Por meio da Figura 1, verifica-se que Região com maior número de domicílios particulares sem espaçamento em aglomerados subnormais, mais de $80 \%$ do total, é a Nordeste. Esse aspecto mostra a concorrência pelo solo urbano, refletida na especulaçáo imobiliária até mesmo em localidades com déficit de serviços básicos, que impóe a ocupação densa e impacta diretamente na salubridade dos ambientes, uma vez que com esta configuração, torna-se difícil a circulação de ar, além de que alterações em uma edificação, podem influenciar diretamente nas que estão em sua proximidade.

Em termos de ocupação em localidades de preservação permanente ou de risco, o que expóe ao risco a sociedade e o ambiente, este estudo do IBGE (2013) mostrou que os aglomerados subnormais do Brasil estão predominantemente localizados em: margens de córregos e rios ou lagos e lagoas; palafitas; praias ou dunas; manguezais; unidades de conservação; aterros sanitários; lixões ou áreas contaminadas; faixa de domínio de rodovias; faixas de domínio de ferrovias; faixas de domínio de gasodutos ou oleodutos; em faixas de domínio de linhas de transmissão de alta tensão. As regiôes metropolitanas de Natal e Fortaleza têm grande parte dos assentamentos subnormais que ocuparam áreas de praias e dunas em seu território, 9.023 e 5.529 domicílios, respectivamente.

O IBGE (2011) mostra que a taxa de analfabetismo é muito maior e a renda per capita muito menor em aglomerados subnormais do que em áreas regulares nos municípios que detêm esse tipo de ocupação. A Figura 2 expressa o comparativo da taxa de analfabetismo por faixa etária entre aglomerados subnormais e áreas urbanas regulares. 
Figura 2 - Grau de analfabetismo por faixa etária em aglomerados subnormais e áreas urbanas regulares.

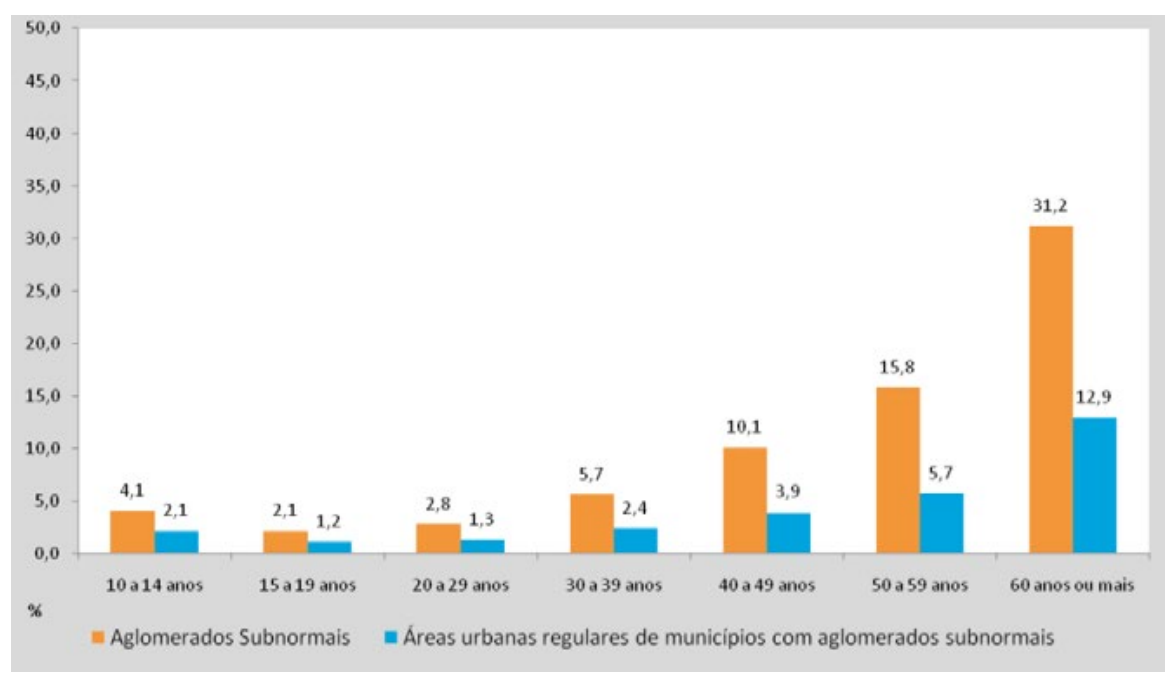

Fonte: IBGE, 2011, Censo Demográfico 2010.

A Figura 3 mostra os rendimentos per capita de domicílios em aglomerados subnormais e áreas urbanas regulares.

Figura 3 - Rendimentos per capita de domicílios em aglomerados subnormais e áreas urbanas regulares.

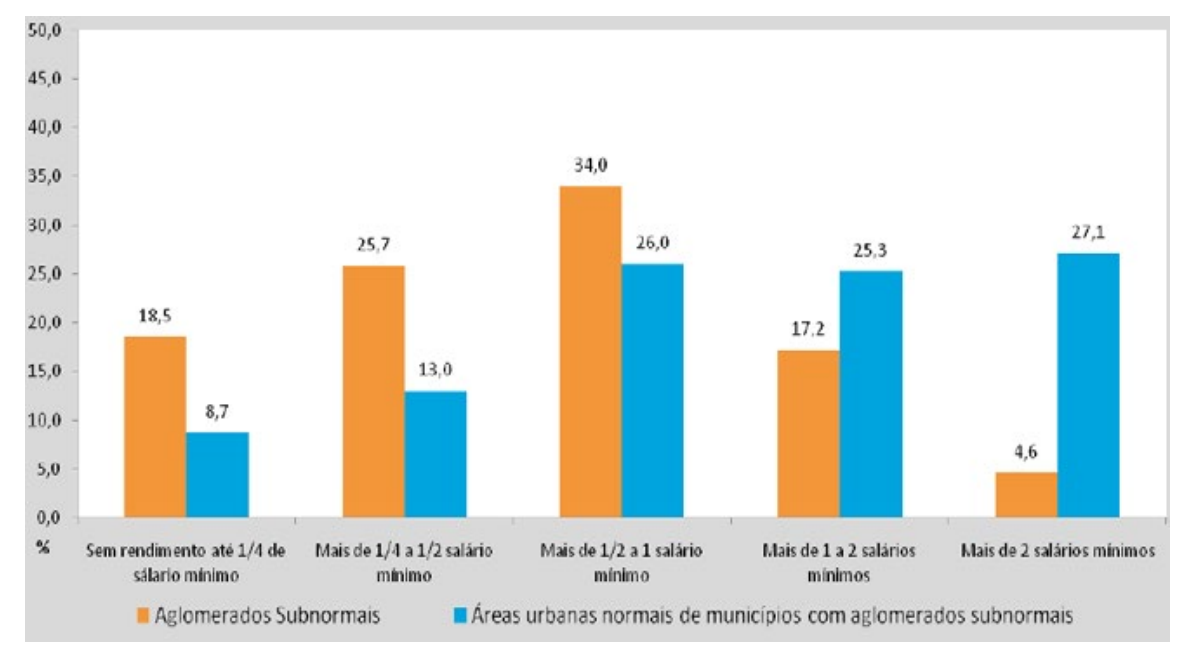

Fonte: IBGE, 2011, Censo Demográfico 2010.

Dessa forma, nota-se que o processo de (des)estruturação urbana brasileiro foi decisivo para que as cidades possuíssem as características atuais, e assim, faz-se necessário buscar reparar os danos propiciados à população através de práticas de planejamento. Nunes 
e Figueiredo Junior (2018) discorrem que há uma necessidade explícita de gerir o solo urbano, de modo a garantir condiçóes de vida favoráveis para a populaçáo, e dentre as preocupaçóes está a segurança habitacional.

Existem vários instrumentos que apresentam alternativas de ordenamento do território: legislaçóes federais, estaduais, municipais, que têm como objetivo orientar o crescimento das cidades, uso e ocupação do solo. Dentre eles pode-se citar: lei 6.766/1979, de parcelamento do solo urbano (BRASIL, 1979); lei 10.257/2001 (Estatuto da Cidade) (BRASIL, 2001); lei orgânica; código tributário; código de obras; código de posturas e outras.

Há ainda legislaçôes recentes, como é o caso das leis 11.977/2009 (BRASIL, 2009) e 13.465/2017 (BRASIL, 2017) e do Decreto 9.310/2018 (BRASIL, 2018), que são marcos na regularização fundiária urbana, uma ação necessária na busca do ordenamento territorial e redução das disparidades socioambientais. A regularização fundiária jurídico dominial de interesse social é um reconhecimento de comunidades consolidadas em um território, que integra a população à cidade formal, reduzindo as desigualdades, garantindo o direito social à moradia e permitindo a execução da função social da propriedade (ARRUDA; LUMBADO, 2019).

\section{Metodologia}

\section{1 Área de estudo}

A área objeto de estudo deste trabalho é o Núcleo Urbano Nossa Senhora de Guadalupe, integrante da área urbana do município de São Miguel/RN. A Figura 4 mostra a localização de São Miguel/RN e destaca o Núcleo Nossa Senhora de Guadalupe. 
Figura 4 - Localização de São Miguel/RN e do Núcleo Urbano Nossa Senhora de Guadalupe.
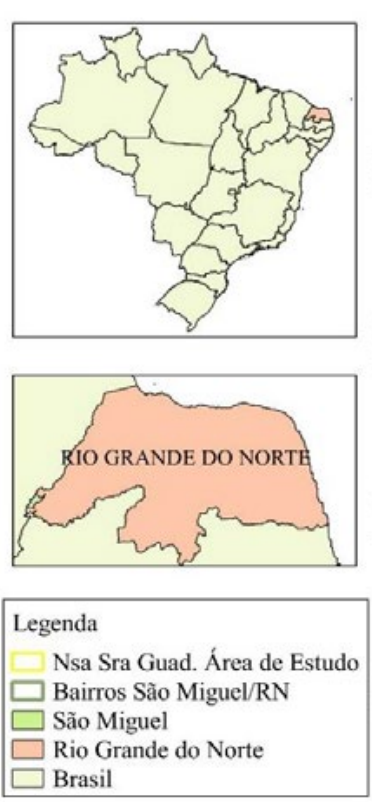

Datum: SIRGAS 2000

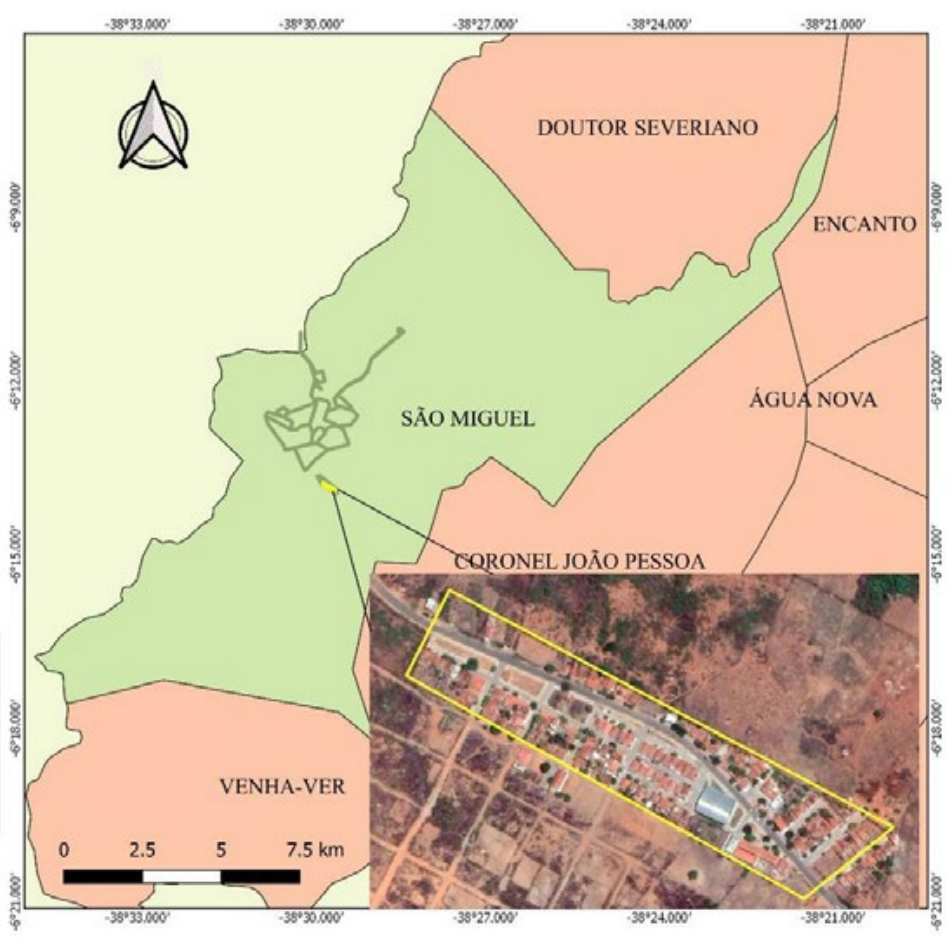

Fonte: Malhas Digitais do IBGE, 2019; Prefeitura Municipal de São Miguel/RN, 2017; e Google Earth Pro, 2018. Elaboração Gráfica realizada pelos Autores, 2020.

Segundo a Prefeitura Municipal de São Miguel/RN (2017), em 1936, por meio da Lei no 88 de 12 dezembro, Sáo Miguel se tornou cidade. Foram desmembrados de seu território os distritos Mundo Novo (em 1962), Baixio de Nazaré (em 1963) e Padre Cosme (em 1992), atualmente denominados Doutor Severiano, Coronel João Pessoa e Venha-Ver, respectivamente.

O município de São Miguel/RN situa-se na mesorregião Oeste Potiguar e na microrregiāo Serra de São Miguel. A sede do município tem uma altitude média de 679 $\mathrm{m}$ e coordenadas $06^{\circ} 12^{\prime} 43,2^{\prime \prime}$ de latitude sul e $38^{\circ} 29^{\prime} 49,2^{\prime \prime}$ de longitude oeste, distando da capital do Rio Grande do Norte cerca de $460 \mathrm{~km}$. Encontra-se totalmente inserido nos domínios da bacia hidrográfica Apodi-Mossoró, sendo banhado apenas por cursos d'água secundários e intermitentes. O Clima é tropical chuvoso com verão seco e estação chuvosa adiantando-se para o outono. A vegetação é composta pela caatinga hiperxerófila, vegetação de caráter mais seco com abundância de cactáceas e plantas de porte mais baixo e espalhadas, e pela Floresta Caducifólia, que apresenta espécies de folhas pequenas e caducas que caem no período seco (Companhia de Pesquisa de Recursos Minerais - CPRM, 2005).

Este município, de acordo com o censo de 2010 do IBGE, possui 27.745 habitantes, sendo a maior parte desta população urbana, uma vez que é constituída por 14.500 habitantes na zona urbana e 7.657 na zona rural, com representatividades percentuais de 
$65,44 \%$ e 34,56\%, respectivamente. O IBGE (2011) expressa que 52,1\% da população de São Miguel/RN tem renda mensal igual ou superior a meio salário mínimo e a mortalidade infantil é de 15,58 óbitos por mil nascidos vivos. O Atlas Brasil (2010) expressa que Índice de Desenvolvimento Humano Municipal (IDHM), que envolve variáveis de renda educação e longevidade, é de 0,606, classificado como médio. Em se tratando de Produto Interno Bruto (PIB) sua maioria é composta pela prestação de serviços, seguida pela agropecuária e, em último lugar, pela indústria. O IBGE (2017) expóe que o PIB per capita deste município foi de $\mathrm{R} \$ 9.247,75$ em 2017, classificando-se na $94^{\mathrm{a}}$ posição entre os 167 municípios norterio-grandenses.

O Núcleo Urbano Nossa Senhora de Guadalupe classifica-se como área de interesse social tanto pelos critérios estabelecidos pela Lei 13.465/2017 (núcleos urbanos informais ocupados predominantemente por população de baixa renda, assim declarados em ato do Poder Executivo municipal) quanto pelo Plano Diretor Participativo desta cidade.

O Art. 28 do Plano Diretor Participativo de São Miguel/RN afirma que são consideradas Áreas Especiais de Interesse Social (AEIS), parte integrante desta lei, aquelas: que se configuram a partir da dimensão socioeconômica e cultural da população com renda familiar não superior a 03 (três) salários mínimos ou renda per capita de até $1 / 2$ salário mínimo ou seu sucedâneo legal; que apresentem atributos morfológicos dos assentamentos - uso predominantemente residencial, tipologia habitacional, traçado e parcelamento característicos de baixa renda, bem como se configurem terrenos ocupados por loteamentos irregulares ou assentamentos informais; que apresentem situação fundiária desfavorável ao ocupante; que sejam passíveis de urbanização de acordo com estudo de viabilidade técnica, considerando os padrôes mínimos de salubridade e segurança; que apresentem precariedade ou ausência de serviços de infraestrutura básica; que possuírem densidade habitacional nunca inferior a 30 (trinta) residências por hectare.

O referido Núcleo foi regularizado pelo Programa Acesso à Terra Urbanizada, proveniente de uma parceria entre a Universidade Federal Rural do Semi-Árido (UFERSA) e o extinto Ministério das Cidades, que teve como principal finalidade promover a Regularização Fundiária de Interesse Social em áreas urbanas de municípios do Semiárido Nordestino, com meta geral de 3.300 lotes, sendo iniciado em outubro de 2014 e concluído em junho de 2018. Este programa atuou em 10 municípios (São Miguel/RN, Venha-Ver/ RN, Portalegre/RN, Encanto/RN, Luís Gomes/RN, Janduís/RN, Tibau/RN, Assu/RN, Carnaubais/RN e Governador Dix-Sept Rosado/RN) regularizando áreas de dominialidade municipal, sendo o responsável pela emissão do primeiro título do Rio Grande do Norte nos moldes da Lei 13.465/2017.

\subsection{Procedimentos metodológicos}

Para a consolidação deste trabalho, foram necessárias três etapas:

a) Acompanhamento das atividades desenvolvidas pelo Programa Acesso à Terra Urbanizada entre os anos de 2015 e 2018 (caracterização de áreas, trabalho social, cartografia básica, regularização da base imobiliária, levantamento cadastral, levantamento social, elaboração do projeto de regularização fundiária, 
parcelamento do solo, registro e titulação), acesso ao banco de dados por ele produzido e realização visitas in loco para que fosse executada a descrição do Núcleo Nossa Senhora de Guadalupe;

b) Aplicação entrevistas não estruturadas com moradores do Nossa Senhora de Guadalupe com o objetivo de analisar o histórico de constituição e expansão do Núcleo adotando como base as indagaçóes: Quantos anos você tem? Há quando tempo reside na cidade de São Miguel/RN? Conte sobre o antes o depois da cidade de São Miguel/RN; Quais as mudanças na infraestrutura ocorridas ao longo do tempo? e outras que foram sendo realizadas no decorrer do diálogo voltadas para o Núcleo objeto de estudo desta pesquisa. Essas entrevistas compuseram uma pesquisa maior, a Dissertação de Mestrado intitulada "Dinâmica Urbana e Regularização Fundiária: um estudo acerca da cidade de São Miguel/RN", que concretizou entrevistas em todos os bairros da cidade de São Miguel/RN. Logo, foram utilizadas para este artigo as entrevistas do Núcleo Nossa Senhora de Guadalupe (duas entrevistas). Os moradores entrevistados tinham idade igual ou superior a 60 anos e residiam em São Miguel/RN há pelo menos 30 (trinta) anos (incluindo o tempo de estadia no Núcleo Nossa Senhora de Guadalupe e em outros bairros), intervalo de tempo que permite uma percepção de mudanças que possam ter ocorrido no cenário urbano, estavam aptas a responder às perguntas e que concordaram em colaborar de forma voluntária para esta pesquisa. $\mathrm{O}$ tamanho da amostra composta por moradores foi definido com base no critério de saturação, que é conceituado por Fontanella, Ricas e Turato (2008) como uma ferramenta utilizada em pesquisas qualitativas para estabelecer o tamanho da amostra de um estudo, através da qual é suspensa a inclusão de novos participantes quando os resultados são considerados repetitivos pelo pesquisador, o que implica que sua continuidade não contribui significativamente para a análise em questão. Solicitou-se aos participantes entrevistados a assinatura do Termo de Consentimento Livre e Esclarecido e do Termo de Autorização para Uso de Áudio. Diante desses instrumentos, as entrevistas foram gravadas. Com a finalidade de garantir o anonimato dos moradores entrevistados, estes foram nomeados como Entrevistado seguido do nome do bairro que ele habita. Esses procedimentos metodológicos foram condicionados à aprovação do Comitê de Ética Profissional da Universidade do Estado do Rio Grande do Norte, com parecer sob o número 2.610.860, datado de 20 de abril de 2018. Considerando a estruturação mais coesa e a atuação no Núcleo desde a sua constituição de um dos moradores entrevistados, os textos deste artigo que relatam entrevistas, referem-se às falas dele.

c) Comparação das particularidades do objeto de estudo deste trabalho com as características do Núcleo Urbano Tôta Barbosa, também pertencente a São Miguel/RN (Figura 5), descritas em Lima e Sousa Junior (2020). O Núcleo Tôta Barbosa é de Interesse Social e foi regularizado à mesma época que o Nossa Senhora de Guadalupe. Assim, essa comparação tem a finalidade de verificar 
similaridades ou disparidades em áreas classificadas como de interesse social em um mesmo município.

Registros cartorários mostram que a intenção de ocupação do Núcleo Tôta Barbosa ocorreu em 1994, quando houve uma desapropriação amigável para a construção de um ginásio poliesportivo e de casas populares (LIMA; SOUSA JUNIOR, 2020).

Figura 5 - Localização do Núcleo Urbano Tôta Barbosa em São Miguel/RN.
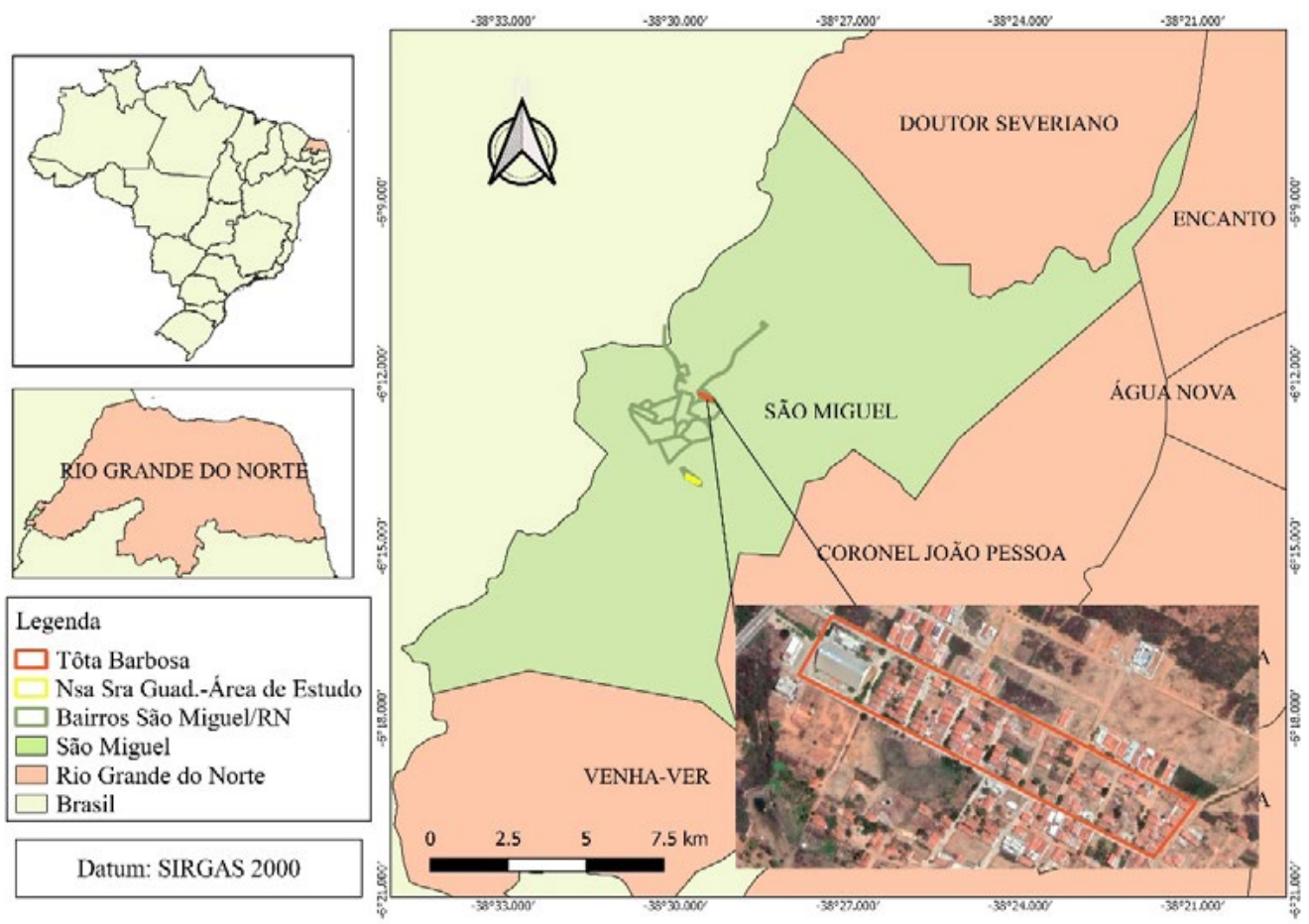

Fonte: Malhas Digitais do IBGE, 2019; Prefeitura Municipal de São Miguel/RN, 2017; e Google Earth Pro, 2018. Elaboração Gráfica realizada pelos Autores, 2020.

\section{Características socioespaciais do Núcleo Urbano Nossa Senhora de Guadalupe}

O Núcleo Urbano Nossa Senhora de Guadalupe tem matrícula da gleba sob no 196 , fls. 15 do livro 2B - Registro Geral de Imóveis, datada de 12 de Abril de 1983, conforme identificação na etapa de caracterização de áreas do Programa Acesso à Terra Urbanizada. Morador participante deste estudo do Núcleo Urbano Nossa Senhora de Guadalupe (antes Vila Oiteiro) declarou que o desmatamento da vegetação do local se iniciou em 1988 e; que esta atividade e a edificação das residências foram realizadas mediante mutirão, no qual os pedreiros doavam três dias de serviço por semana e os serventes não recebiam nenhuma remuneração pelo seu serviço na expectativa de serem contemplados com uma casa, que era destinada por meio de sorteio. Ou seja, mesmo que se trabalhasse por vários meses de forma gratuita, não havia a garantia da concessão da residência. Segundo o morador, as 
unidades habitacionais doadas correspondiam à metade de uma casa, contendo apenas um quarto e um corredor, sem banheiro e com piso de chão batido; com o decorrer do tempo, foram destinados projetos de construção de banheiros e hoje as residências já dispóem desta infraestrutura. Essas características demonstram a vulnerabilidade social e espacial a que os moradores enfrentaram desde a constituição do núcleo urbano.

Para Maricato (2013) grande parte das cidades brasileiras é construída pelos moradores em áreas invadidas, muitas delas ambientalmente frágeis ou de loteamentos ilegais. A autora enfatiza que esses bairros não foram construídos a partir da contribuição de engenheiros, arquitetos, nem observando as leis urbanísticas e ambientais, mas foram consolidados a partir da força de trabalho barata, segregada e excluída que náo tem condiçóes de se inserir no mercado residencial privado legal, altamente especulativo. O Núcleo Urbano em análise não foi invadido nem é um loteamento ilegal. Porém, se configurou como irregular até o ano de 2018 e, portanto, integrava o grupo de áreas informais constituídas sem ordenamento e por pessoas sem condiçôes financeiras de adquirirem seu imóvel, que inclusive, trabalharam na construção desta área, como expõe o relato do morador anteriormente citado.

Cartas de aforamento da localidade emitidas pelo município mostram que a concessão do uso das residências foi feita em dezembro de 1992. Assim como no Núcleo Urbano de Interesse Social Tôta Barbosa (LIMA; SOUSA JUNIOR, 2020), houve um prazo de concessão do uso das áreas do Núcleo Nossa Senhora de Guadalupe de 20 anos, existindo a necessidade de os beneficiários realizarem construção ou plantação em até um ano após o recebimento da autorizaçáo, o que traduz as características rurais que esta localidade tinha no ano de 1992.

As redes de água e energia elétrica eram inexistentes no início da ocupação. A primeira casa a dispor de energia elétrica foi a de um morador entrevistado, que declarou custear a ligação dos cabos do poste até sua residência, e que afirma que no decorrer dos anos, os gestores municipais foram promovendo a distribuição para as demais residências. No que se refere à água, segundo o morador, a forma de acesso inicial no bairro ocorreu por meio de Chafariz, com horário pré-determinado e quantidade restrita para que a populaçáo coletasse e realizasse o transporte até sua residência. No decorrer dos anos foram sendo feitas as instalaçóes para as moradias. Morador entrevistado expóe que a pavimentaçấo demorou muitos anos para "chegar".

A Figura 6 corresponde ao levantamento planialtimétrico executado pelo Programa Acesso à Terra Urbanizada para o Núcleo Urbano Nossa Senhora de Guadalupe. 
Figura 6 - Levantamento Planialtimétrico Nossa Senhora de Guadalupe - São Miguel/RN.

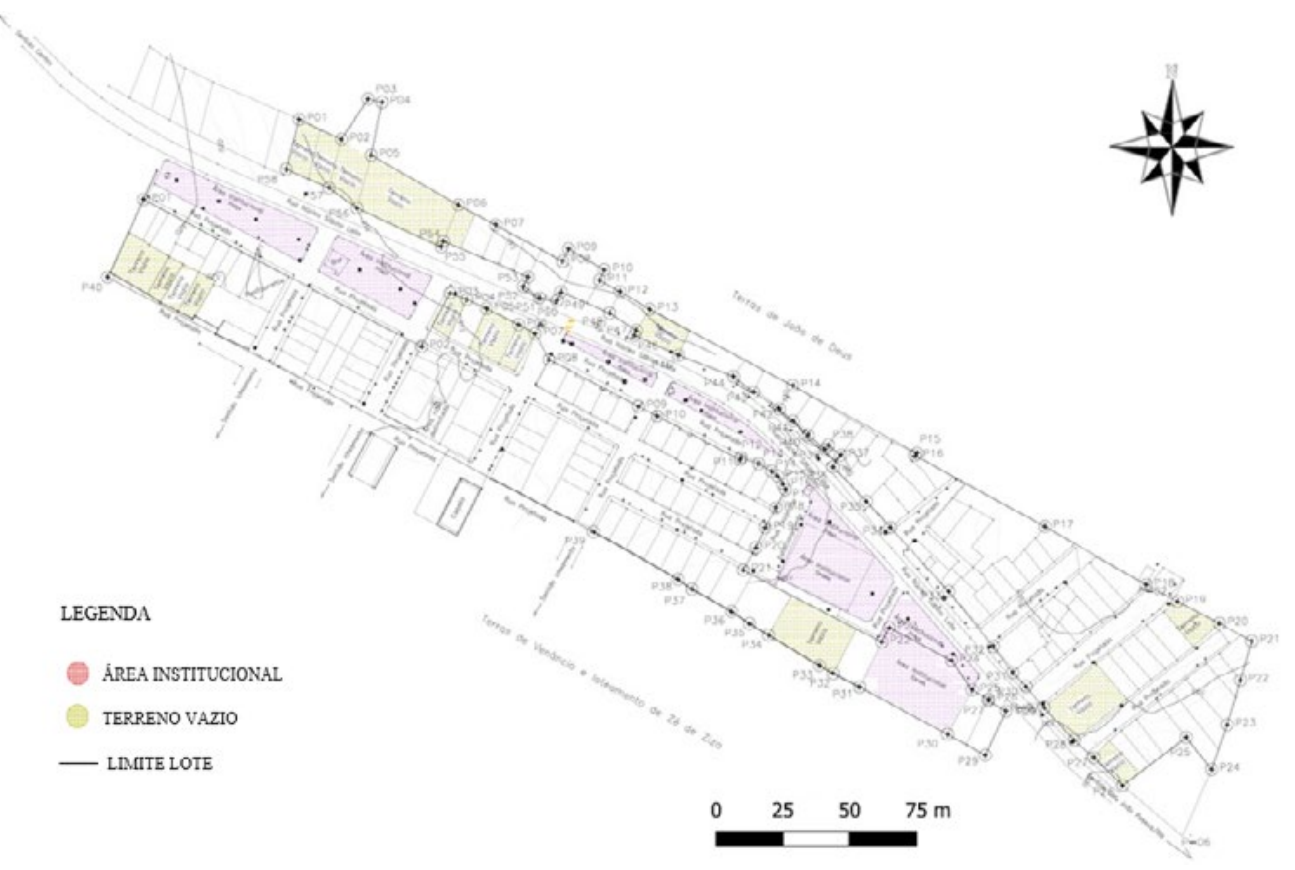

Fonte: Acervo de Dados do Programa Acesso à Terra Urbanizada, 2017. Adaptado.

Por meio da Figura 6, verifica-se que as ruas e os lotes que confrontam com as Terras de Venâncio (área limitante ao sul do Núcleo Urbano Nossa Senhora de Guadalupe) apresentam proporcionalidade, entretanto as ruas e lotes que confrontam que as Terras de João de Deus (área limitante ao norte do Núcleo Urbano Nossa Senhora de Guadalupe) não seguem um direcionamento e os lotes têm dimensóes bastante díspares. Nota-se a existência de praças públicas, quadra poliesportiva e escola neste núcleo urbano na poligonal com registro em cartório. A matrícula mãe do núcleo urbano contém averbação de desmembramento no ano de 2008 da área destinada à construção do ginásio poliesportivo. Além desses equipamentos, existe uma igreja que se localiza no limite da poligonal de interesse para fins de regularizaçáo fundiária e que também é um local de interatividade dos moradores do bairro. A Figura 7 expóe estes elementos infraestruturais. 
Figura 7 - Equipamentos Urbanos Nossa Senhora de Guadalupe.

a) Quadra Poliesportiva

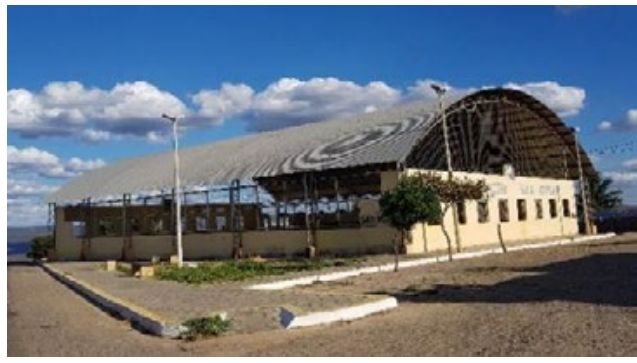

c) Praça

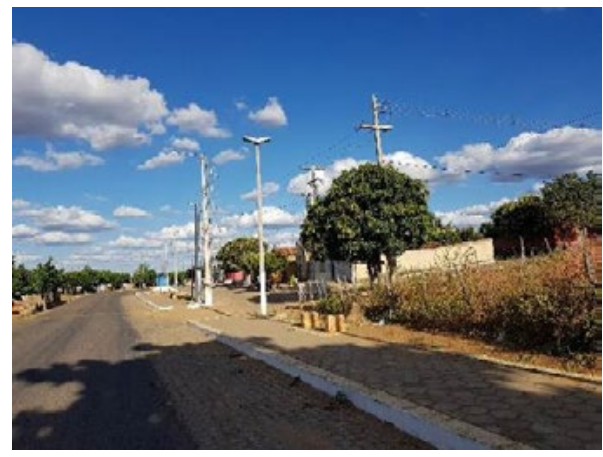

b) Escola

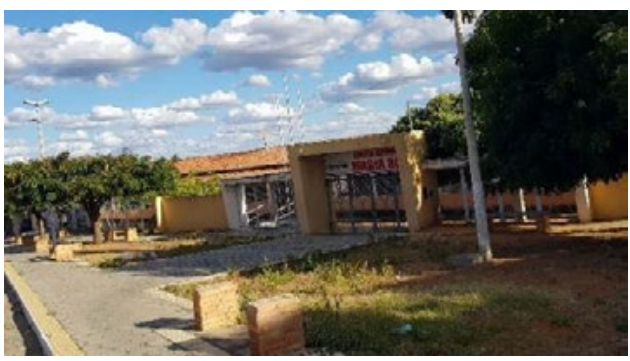

d) Igreja

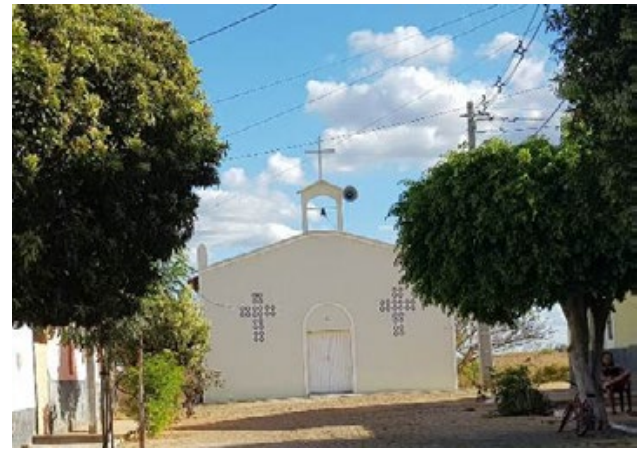

Fonte: Autoria Própria, 2018.

As praças, jardins e logradouros, espaços residenciais, comerciais, industriais e equipamentos urbanos comunitários edificados concorrem para a estruturação e qualificação da cidade (MORAES; GOUDARD; OLIVEIRA, 2008).

O levantamento planialtimétrico exibe também a existência de uma Rodovia, a RN 177, que influenciou no processo de Regularização Fundiária de Interesse Social a que o núcleo foi submetido, uma vez que foi necessário realizar análise a respeito dos limites de faixa de domínio da rodovia e a legalidade das construçóes no entorno, tendo em vista o que dispóe a Lei 6.024/1991, sobre a licença prévia para edificaçóes de imóveis ou cercas às margens de rodovias estaduais, e dá outras providências. Esta lei rege que no Rio Grande do Norte a faixa de domínio compreende a área de terra limitada pela distância mínima de 20 metros para cada lado da rodovia a partir do eixo da pista de rolamento. Descreve ainda que as edificaçóes devem estar recuadas a 15 metros dos limites externos da faixa de domínio, ou seja, para cumprirem com o disposto na lei, as construçóes localizadas às margens de rodovias do Estado do Rio Grande do Norte devem distar 35 metros do eixo da faixa de rolamento. Esse recuo pode ter dimensão reduzida no perímetro urbano, desde que prevista em instrumento municipal e que se resguarde a segurança do trânsito e do tráfego. Edificaçóes anteriores à lei não são penalizadas por estarem instaladas em recuo inferior ao previsto em lei. Dessa forma, ainda que os proprietários atendessem os demais requisitos legais para a regularização fundiária, foi verificada a distância ao eixo da RN 177 
e o ano de construção das edificações e assim foi constatado se os imóveis haviam ou não sido construídos antes de entrar em vigor a lei que impede a construção de imóveis na faixa de domínio da rodovia. Verificou-se que os imóveis foram edificados antes desta Lei e, a regularização foi concretizada.

A Figura 8 corresponde à planta de parcelamento do Núcleo Urbano Nossa Senhora de Guadalupe.

Figura 8 - Planta de Parcelamento do Nossa Senhora de Guadalupe - São Miguel/RN.

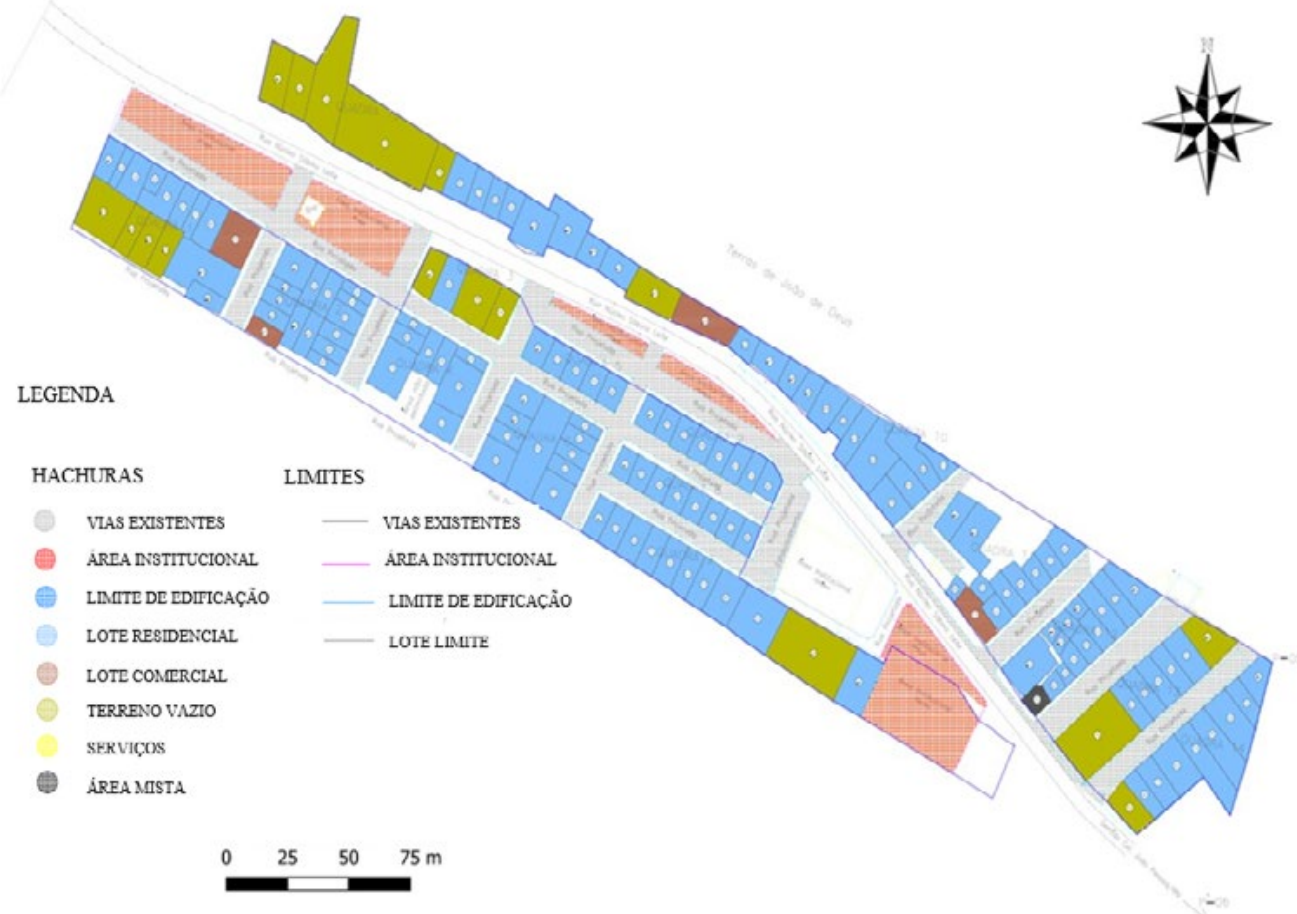

Fonte: Acervo de Dados do Programa Acesso à Terra Urbanizada, 2017. Adaptado.

Nota-se a ausência de padróes nas quadras e lotes, especialmente para as quadras $10,11,12$ e 13 . Os menores lotes estáo localizados nestas quadras, sendo o menor lote com área de $33,80 \mathrm{~m}^{2}$, pertencente à quadra 12. Morador entrevistado declarou que essas quadras tiveram suas construçóes a partir da iniciativa da populaçáo ocupante e que apenas as quadras de 1 a 9 foram construídas pela Prefeitura Municipal de São Miguel/RN em duas etapas. Logo, a diferença existente entre os dois lados da rodovia pode estar associada a este fator.

A planta urbanística contempla as áreas de cada lote e permite de identificação da classificação de cada um por meio de hachuras diferenciadas. O Projeto de Regularização Fundiária do Núcleo Nossa Senhora de Guadalupe mostra que ele é formado por 152 lotes, excetuando-se as áreas institucionais e um bar que está inserido em uma dessas áreas institucionais, classificados de acordo com a Tabela 1. 
Tabela 1 - Classificação dos lotes do Núcleo Urbano Nossa Senhora de Guadalupe.

\begin{tabular}{c|c}
\hline LOTES & QUANTIDADE \\
\hline Lotes Residenciais & 130 \\
\hline Lotes Comerciais & 4 \\
\hline Lotes Mistos & 1 \\
\hline Terrenos Vazios & 17 \\
\hline TOTAL & $\mathbf{1 5 2}$ \\
\hline
\end{tabular}

Fonte: Acervo de Dados do Programa Acesso à Terra Urbanizada, 2016.

A Tabela 1 mostra que os lotes residenciais são a maioria, aspecto que corrobora uma das características de AEIS expressas no Plano Diretor Participativo de São Miguel/RN: uso predominantemente residencial. Ao contrário do Núcleo Tôta Barbosa, em que os lotes vazios têm representatividade de $31 \%$ do total de lotes existentes (o total de lotes é de 135, sendo 88 residenciais, 5 mistos e 42 vazios), o Núcleo Urbano Nossa Senhora de Guadalupe possui o equivalente a $11 \%$ de lotes com esta configuração.

A ocupação de áreas segundo os elementos que compóem o Núcleo Urbano Nossa Senhora de Guadalupe é expressa na Tabela 2.

Tabela 2 - Tabela de Áreas Nossa Senhora de Guadalupe

\begin{tabular}{c|r|r}
\hline ESPECIFICAÇÃO & ÁREAS $\left.\mathbf{( m}^{\mathbf{2}}\right)$ & \multicolumn{2}{c}{$\%$} \\
\hline Áreas de lotes (152 lotes) & $22.198,97$ & 54,67 \\
\hline Sistema Viário & $13.435,20$ & 33,09 \\
\hline Áreas Institucionais & $4.973,75$ & 12,24 \\
\hline Área Loteada & $40.607,92$ & 100,00 \\
\hline Total da Gleba & $\mathbf{4 0 . 6 0 7 , 9 2}$ & $\mathbf{1 0 0 , 0 0}$ \\
\hline
\end{tabular}

Fonte: Acervo de Dados do Programa Acesso à Terra Urbanizada, 2016.

Os lotes estão distribuídos em 14 quadras, como mostra a Tabela 3.

Tabela 3 - Distribuição de Lotes em Quadras - Nossa Senhora de Guadalupe

\begin{tabular}{c|c}
\hline QUADRAS & No DE LOTES \\
\hline QUADRA 1 & 15 \\
\hline QUADRA 2 & 15 \\
\hline QUADRA 3 & 4 \\
\hline QUADRA 4 & 8 \\
\hline QUADRA 5 & 5 \\
\hline QUADRA 6 & 10 \\
\hline QUADRA 7 & 8 \\
\hline QUADRA 8 & 8 \\
\hline QUADRA 9 & 11 \\
\hline
\end{tabular}




\begin{tabular}{c|c}
\hline QUADRAS & No DE LOTES \\
\hline QUADRA 10 & 27 \\
\hline QUADRA 11 & 11 \\
\hline QUADRA 12 & 14 \\
\hline QUADRA 13 & 7 \\
\hline QUADRA 14 & 9 \\
\hline
\end{tabular}

Fonte: Acervo de Dados do Programa Acesso à Terra Urbanizada, 2016.

A Tabela 3 expóe que há uma divisão desigual de lotes por quadra, diferentemente do que ocorre no Núcleo Tôta Barbosa, que segue proporcionalidade no quantitativo de lotes por quadra, com o total de 16 a 18 lotes por quadra (LIMA; SOUSA JUNIOR, 2020). A distribuição dos lotes por categoria (residencial, comercial, misto, vazio) é apresentada na Figura 9.

Figura 9 - Representação de lotes por categoria - Nossa Senhora de Guadalupe.

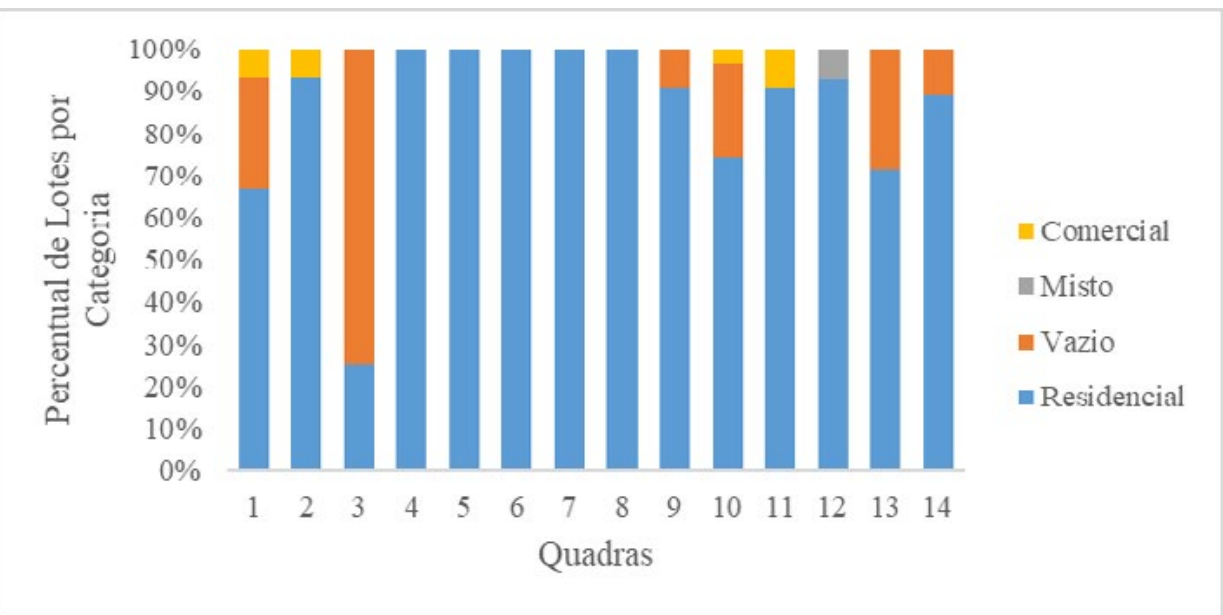

Fonte: Acervo de Dados do Programa Acesso à Terra Urbanizada, 2016. Elaboração Gráfica realizada pelos Autores, 2018.

A Figura 9 mostra que a quadra 3 é a única que possui mais lotes vazios do que residenciais. Entretanto, esta quadra é composta por apenas quatro lotes, o que pode ser verificado com a Figura 8, sendo um deles habitacional e três vazios. Nota-se a presença de lotes comerciais e um lote misto, realidade distinta do Núcleo Urbano Tôta Barbosa, que não possui lotes comerciais em seu território. Os lotes destinados a comércio do Nossa Senhora de Guadalupe são: oficina, bares e restaurante.

No que se refere às dimensões dos lotes, se considerássemos a área mínima de $125 \mathrm{~m}^{2}$ e frente mínima de 5 metros, especificadas pela Lei 6.766/1979 para loteamentos do tipo padrão, 70 lotes atenderiam estas características. Observando as recomendações urbanísticas correspondentes à área e dimensão de frente contidas nos arts. 36 e 104 do Plano Diretor Participativo de São Miguel/RN para novos loteamentos em AEIS (lote mínimo de $100 \mathrm{~m}^{2}$, frente mínima de 6 metros e lote máximo de $200 \mathrm{~m}^{2}$, com frente mínima de 8 metros), 
verifica-se que neste Núcleo Urbano existe 54 lotes com área inferior a 100 $\mathrm{m}^{2}, 69$ com área maior que $100 \mathrm{~m}^{2}$ e menor ou igual que $200 \mathrm{~m}^{2}$, e 29 lotes com área superior a $200 \mathrm{~m}^{2}$. A Figura 10 mostra a representação em percentual dos lotes de acordo com suas áreas.

Figura 10 - Dimensões dos Lotes do Núcleo Urbano Nossa Senhora de Guadalupe.

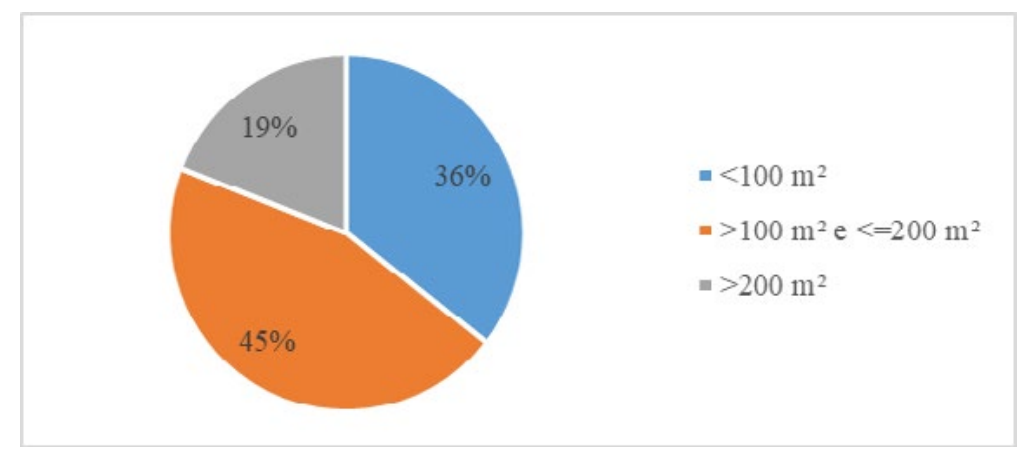

Fonte: Acervo de Dados do Programa Acesso à Terra Urbanizada, 2016. Elaboração Gráfica realizada pelos Autores, 2018.

Avaliando o cenário mostrado na Figura 10, verifica-se que $45 \%$ dos lotes atenderiam ao critério de área entre $100 \mathrm{~m}^{2}$ e $200 \mathrm{~m}^{2}$ explicitado no Plano Diretor Participativo de São Miguel/RN para novos loteamentos em AEIS. O Núcleo Urbano Tôta Barbosa (LIMA; SOUSA JUNIOR, 2020) possui $81 \%$ dos lotes enquadrados neste intervalo de área e apenas $8 \%$ com área inferior a $100 \mathrm{~m}^{2}$, aspecto que pode ser considerado como fragilidade do Núcleo Urbano Nossa Senhora de Guadalupe frente ao Núcleo Urbano Tôta Barbosa, já que a dimensão do lote pode impactar no conforto da habitação. Observando a dimensão da frente dos 69 lotes com área entre $100 \mathrm{~m}^{2}$ e $200 \mathrm{~m}^{2}$ do Nossa Senhora de Guadalupe por meio do cadastro físico preparado pelo Programa Acesso à Terra Urbanizada, identifica-se que os lotes 110 da quadra 1 e 110 da quadra 2 não atenderiam a dimensão mínima de frente para novos loteamentos em AEIS, pois para eles esta medida é de 5,89 metros e 5,90 metros, respectivamente. O Quadro 1 mostra este cenário para o Lote 110 - Quadra 1. 
Quadro 1: Cadastro Físico Quadra 1 - Lote 110 - Nossa Senhora de Guadalupe, São Miguel/RN

\begin{tabular}{|l|}
\hline \multicolumn{1}{|c|}{ CADASTRO FÍSICO } \\
\hline Codificação: \\
\hline Identificaçáo: Quadra 1 - Lote 110 \\
\hline Caracterizaçáo do Uso: Residencial \\
\hline Condiçóes de Moradia: Adequado \\
\hline Área do Lote (m²): 100.31 \\
\hline Delimitaçáo dos Lotes: \\
Frente: $5.89 \mathrm{~m}$ (Rua Projetada) \\
Direita: $15.42 \mathrm{~m}$ (Rua Projetada) \\
Fundo: $7.10 \mathrm{~m}$ (Lote 100$)$ \\
Esquerda: $15.24 \mathrm{~m}$ (Lote 100$)$ \\
\hline
\end{tabular}

Fonte: Acervo de Dados do Programa Acesso à Terra Urbanizada, 2016.

Porém, o art. 11, $\$ 1^{\circ}$ da Lei 13.465/2017 rege que para fins de Reurb, os Municípios poderão dispensar as exigências relativas ao percentual e às dimensóes de áreas destinadas ao uso público ou ao tamanho dos lotes regularizados, assim como outros parâmetros urbanísticos e edilícios. Além disso, os parâmetros urbanísticos definidos no plano diretor para AEIS são referentes a novos loteamentos e AEIS não regulamentadas. Dessa forma, os lotes que estavam enquadrados nos critérios passíveis de recebimento da legitimação fundiária instrumento adotado para a regularização deste núcleo, foram registrados em nome dos moradores. Esses critérios são expostos no art. $23 \$ 1^{\circ}$ da Lei 13.465/2017: beneficiário não concessionário, foreiro ou proprietário de outro imóvel urbano ou rural; beneficiário não contemplado com legitimação de posse ou fundiária de imóvel urbano da mesma finalidade, ainda que situado em núcleo urbano distinto; no caso de imóvel urbano com finalidade não residencial, que seja reconhecido pelo poder público o interesse público de sua ocupação.

O memorial descritivo (componente do projeto de regularização fundiária) emitido pelo Programa Acesso à Terra Urbanizada (2016) para esta área apresenta características referentes a: áreas vulneráveis (alagadiças, aterradas, declividades acentuadas, geologicamente frágeis); corpos d'água, vales secos e linhas de drenagem natural; declividades predominantes; existência de rodovias, ferrovias, adutoras e redes de transmissão de energia; construçóes existentes a demolir ou não. Nesta perspectiva, o Núcleo Urbano Nossa Senhora de Guadalupe não apresenta terrenos acidentados e declividades consideráveis, não possui corpos d'água; não dispóe vales; não tem ferrovias, adutoras e a transmissão de energia é realizada por posteamento comum, mas possui rodovia localizada no centro da gleba; não existe casos de construçóes que necessitem de demolição. Essas descriçóes mostram similaridade com a gleba Tôta Barbosa, diferindo apenas pela presença de rodovia, que é próxima aos lotes enquanto a do Tôta Barbosa é uma via de acesso que não possui aproximação com os lotes.

Análise do memorial descritivo da gleba do parcelamento do Núcleo Urbano Nossa Senhora de Guadalupe e cadastro socioeconômico gerados pelo Programa Acesso à Terra Urbanizada (2016) permitiram a detecção da infraestrutura básica (Lei 6.766/1979, art. 
5०: a infraestrutura básica dos parcelamentos é constituída pelos equipamentos urbanos de escoamento das águas pluviais, iluminação pública, esgotamento sanitário, abastecimento de água potável, energia elétrica pública e domiciliar e vias de circulação) deste núcleo urbano:

a) Sistema de Abastecimento de Água Potável - A distribuição de água está inoperante nesta gleba devido o colapso da capacidade do reservatório principal do município de São Miguel: Açude do Bonito. Assim, o abastecimento é feito por carros-pipas.

b) Sistema de Coleta, Afastamento, Tratamento e Disposição Final de Esgoto - A coleta de esgoto náo existe na gleba, dessa forma, os resíduos são destinados às fossas do tipo rudimentar particulares de cada lote.

c) Rede de Distribuição de Energia Elétrica e Sistema de Iluminação Pública Há iluminação pública e distribuição de energia elétrica para os domicílios. As instalações domiciliares são regulares com medidor.

d) Sistema de Drenagem de Águas Pluviais - Não existe sistema de drenagem nessa gleba.

e) Guias e Sarjetas: Não há qualquer guia ou sarjeta nessa gleba.

f) Sistema de Coleta e Destinação do Lixo - A coleta de lixo ocorre na gleba, entretanto não há dados sobre a destinação deste.

g) Pavimentação - A gleba é parcialmente pavimentada. A Tabela 4 expóe os tipos de pavimentação da gleba com suas respectivas áreas e percentuais.

Tabela 4 - Sistema Viário do Núcleo Urbano Nossa Senhora de Guadalupe.

\begin{tabular}{c|c|c}
\hline SISTEMA VIÁRIO & ÁREAS $\left(\mathbf{m}^{\mathbf{2}}\right)$ & $\mathbf{\%}$ \\
\hline Sem Pavimentação & $2.288,43$ & 17,03 \\
\hline Calçamento & $8.108,92$ & 60,36 \\
\hline Asfalto & $3.037,85$ & 22,61 \\
\hline TOTAL & $\mathbf{1 3 . 4 3 5 , 2 0}$ & $\mathbf{1 0 0 , 0 0}$ \\
\hline
\end{tabular}

Fonte: Acervo de Dados do Programa Acesso à Terra Urbanizada, 2016.

Assim como o Tôta Barbosa, o Núcleo Urbano Nossa Senhora de Guadalupe possui deficiências em sua infraestrutura básica no que concerne aos itens escoamento das águas pluviais, abastecimento de água potável, esgotamento sanitário, e vias de circulação, uma vez que o sistema de drenagem é inexistente, o abastecimento é realizado por carros-pipas, não existe coleta de esgoto e parcela das vias náo possui pavimentação. No entanto, no Núcleo Tôta Barbosa três famílias declararam ter poço artesiano responsável pelo suprimento de sua necessidade hídrica (LIMA; SOUSA JUNIOR, 2020) e no Núcleo Urbano Nossa Senhora de Guadalupe nenhuma família participante afirmou dispor deste recurso. Morador do Núcleo Urbano Nossa Senhora de Guadalupe entrevistado falou que devido ao abastecimento de água em caixas d'água públicas, a divisão é desigual: enquanto uns acessam muitos litros outros acessam poucos e ressalta que isso gera a necessidade de aquisição de água de forma 
particular pela população que mesmo com poucos recursos financeiros pode destinar parte deles à esta compra.

O déficit de esgotamento sanitário que assola esta área também é presente a nível municipal e regional, visto que o IBGE (2011) exibe que dos 4.174 domicílios particulares permanentes urbanos existentes em São Miguel/RN, 3.947 tem como sistema de esgotamento sanitário a fossa rudimentar, o equivalente a $94,56 \%$ dos desses domicílios urbanos. A Região Nordeste, por sua vez, detém o segundo menor índice de atendimento de coleta de esgoto em rede das regióes brasileiras (26,9\%), de acordo com o SNIS (2019).

A pavimentação contempla a maior parte o Núcleo Urbano Nossa Senhora de Guadalupe, já que a Tabela 4 expressa que $60,36 \%$ das vias de circulação são atendidas por pavimentação do tipo calçamento e $22,61 \%$ do tipo asfáltico, o que resulta em $82,97 \%$ das ruas com pavimentação, valor $18,02 \%$ superior à pavimentação existente no Núcleo Urbano Tôta Barbosa (64,95\%). Destaca-se que a via sem pavimentação nesta localidade é a correspondente à frente da quadra 10 , uma vez que todas as ruas mostradas na planta de parcelamento (Figura 8) possuem pavimentação do tipo calçamento e a rodovia do tipo asfáltico.

Em se tratando de renda, análise de cadastro socioeconômico realizado pelo Programa Acesso à Terra Urbanizada no ano de 2015, com 72 famílias, mostrou que a renda média domiciliar desta área é de $\mathrm{R} \$ 730,85$. Comparando esse valor com o salário mínimo de 2015 , que era de $\mathrm{R} \$ 788,00$, verifica-se que a renda média domiciliar desta localidade é inferior a um salário mínimo, diferentemente do Núcleo Urbano Tôta Barbosa que apresentou renda média domiciliar de $\mathrm{R} \$ 829,40$ considerando uma amostra de 47 famílias. Este fator configura mais uma fragilidade do Núcleo Urbano Nossa Senhora de Guadalupe em relação ao Núcleo Urbano Tôta Barbosa. A Figura 11 refere-se à distribuição percentual de rendas domiciliares do Núcleo Urbano Nossa Senhora de Guadalupe.

Figura 11 - Renda Mensal Domiciliar Núcleo Urbano Nossa Senhora de Guadalupe.

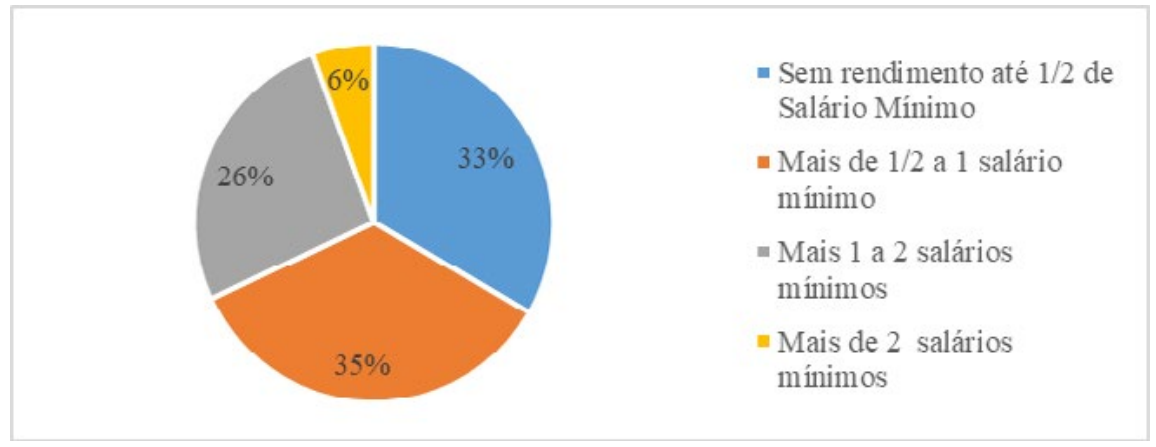

Fonte: Acervo de Dados do Programa Acesso à Terra Urbanizada, 2016. Elaboração Gráfica realizada pelos Autores, 2018.

A observaçâo da Figura 11 permite identificar que as famílias do Núcleo Urbano Nossa Senhora de Guadalupe estão divididas nas classes de renda sem rendimento até meio salário mínimo, mais de meio até um salário e mais de 1 a dois salários mínimos em 
proporções semelhantes. A renda superior a dois salários mínimos por família é escassa, já que apenas 6\% das famílias estâo nesta categoria. Das 72 famílias participantes do cadastro socioeconômico, 24 têm renda de zero a meio salário mínimo, 25 possuem rendimento de mais de meio até um salário mínimo, 19 dispóem de renda de mais de 1 até dois salários mínimos e 4 famílias possuem renda superior a dois salários. Das quatro famílias com renda superior a dois salários, a renda máxima é de $R \$ 2.376,00$, que supera em $R \$$ 12,00 o valor correspondente a três salários mínimos, máxima renda familiar para áreas de interesse social citada no Plano Diretor Participativo de São Miguel/RN, ou seja, nenhuma família ultrapassa a renda teto para ser beneficiária da REURB-S de acordo com o decreto 9.310/2018, isto é, cinco salários mínimos (definida pelo decreto 9.310/2018).

Confrontado essa realidade com a situação de renda do Núcleo Urbano Tôta Barbosa (LIMA, SOUSA JUNIOR, 2020), constata-se que há um maior percentual de famílias inserida na classe de rendimento de zero a meio salário mínimo no Núcleo Urbano Nossa Senhora de Guadalupe, ao mesmo tempo que há menor percentual enquadrado nas classes de renda de mais de meio até um salário mínimo e com mais de um até dois salários mínimos, além de que embora haja maior número percentual de famílias com renda superior a dois salários mínimos (6\% contra 4\% do Núcleo Urbano Tôta Barbosa), a maior renda existente é aproximadamente um salário e meio inferior à maior renda presente no Núcleo Urbano Tôta Barbosa.

Analisando a realidade de São Miguel/RN, que de acordo com o IBGE (2011), tem $20 \%$ dos domicílios particulares permanentes com rendimento de até meio salário mínimo, $20 \%$ acima de meio e até um salário mínimo, 34\% maior que um e menor que dois salários mínimos e $26 \%$ acima de dois salários mínimos, averígua-se que o Núcleo Urbano Nossa Senhora de Guadalupe apresenta índices de renda muito inferiores.

A renda per capita por domicílio da área em análise é mostrada na Figura 12.

Figura 12 - Renda Per Capita Domiciliar Núcleo Urbano Nossa Senhora de Guadalupe.

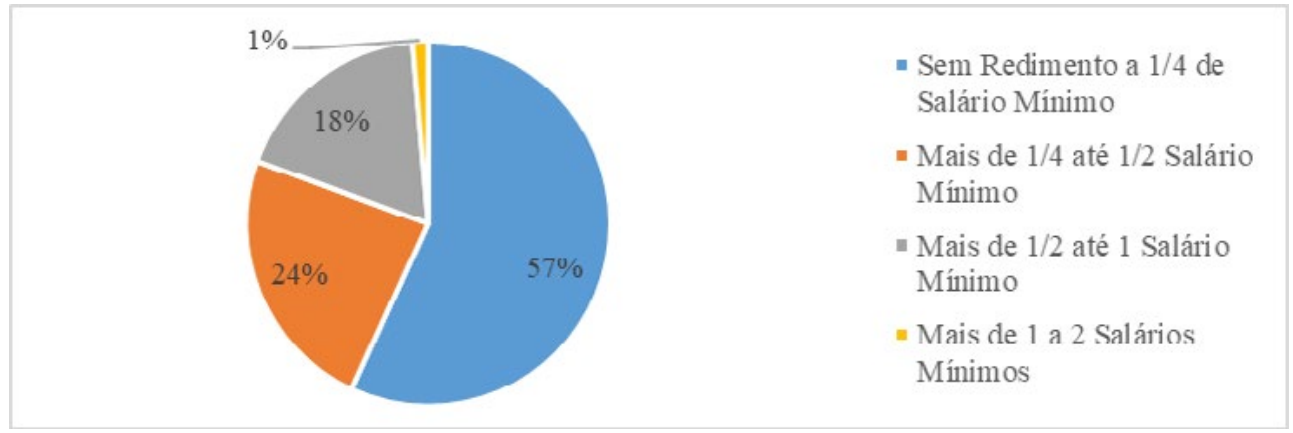

Fonte: Acervo de Dados do Programa Acesso à Terra Urbanizada, 2016. Elaboração Gráfica realizada pelos Autores, 2018.

Por meio da Figura 12, nota-se que o Núcleo Urbano Nossa Senhora de Guadalupe possui vulnerabilidade no quesito renda muito superior aos assentamentos subnormais referenciados na seção deste trabalho que aborda a Irregularidade Fundiária Urbana, uma 
vez que o IBGE (2011) mostrou que 44,2\% da população em aglomerados subnormais tinha renda per capita de até meio salário mínimo enquanto que no Nossa Senhora de Guadalupe $81 \%$ dos domicílios têm renda per capita inserida nesta categoria. Em relação ao Núcleo Urbano Tôta Barbosa, conclui-se que a população do Núcleo Nossa Senhora de Guadalupe apresenta índices de renda mais precários do que ele, pois enquanto este tem $81 \%$ dos domicílios com renda per capita de até meio salário mínimo, aquele tem $66 \%$. A renda per capita desta localidade reafirma a sua condição de AEIS, pois o Plano Diretor Participativo de São Miguel/RN determina como um dos critérios categorização como tal para renda per capita de até meio salário mínimo.

Em termos municipais, o IBGE (2011) mostra que 31\% dos domicílios particulares permanentes de São Miguel/RN têm renda per capita de até um quarto de salário mínimo, enquanto no Nossa Senhora de Guadalupe esse percentual é de 57\%, o que corresponde a $26 \%$ a mais, o que corrobora a fragilidade desta localidade.

No que se refere à valorização imobiliária, morador entrevistado deste Núcleo Urbano afirma que houve aumento do valor dos imóveis se comparado com alguns anos atrás porque antes as pessoas trocavam suas casas por rádio, fogão ou por preços mínimos ("800 contos") e recentemente foram vendidas duas casas vizinhas às suas por 9 mil reais e por 10 mil reais. Entretanto, esse valor é muito baixo se comparado com outras localidades do município que tiveram considerável evolução do preço ao longo dos anos. "Aqui não tem preço não. Aqui é um povo desacreditado em tudo no mundo" (MORADOR DO BAIRRO NOSSA SENHORA DE GUADALUPE, 2018).

As características dos assentamentos informais expostas por Fernandes (2011) e citadas no tópico "Dinâmicas da Irregularidade Fundiária" deste artigo (baixos níveis de renda, planejamento urbano impraticável, falta de terrenos com fornecimento de serviços de rede pública e habitaçóes de cunho social e sistema jurídico falho) são presentes no Núcleo Nossa Senhora de Guadalupe, pois a renda é baixa, sua a configuração espacial e forma de constituição demonstram a ausência de um planejamento urbano e a fragilidade na infraestrutura do terreno público do município no qual este Núcleo foi instalado, a população encontra-se em situação de vulnerabilidade social e havia irregularidade fundiária até o ano de 2018.

Logo, as características sociais e espaciais do Núcleo Urbano Nossa Senhora de Guadalupe revelam que esta área é vulnerável e indicam a condição de prioridade para a implantação de açôes que visem ampliar a qualidade de vida da população. A fachada da edificação exposta no Quadro 1 representa as habitações desta localidade, que são bastante simples, e os índices de renda expóem a fragilidade econômica da área.

\section{Conclusão}

O Núcleo Urbano Nossa Senhora de Guadalupe possui características socioespaciais intrínsecas às áreas consolidadas de maneira informal, uma vez que teve sua constituição sem o planejamento urbano adequado e com parte de sua formação a partir da mão-de-obra dos próprios moradores; parcela de suas quadras não seguem um padrão e contemplam lotes muito pequenos; abriga deficiências na infraestrututa básica, pois não há abastecimento de 
água regular (aspecto que acomete toda a cidade devido a escassez hídrica), inexiste sistema de drenagem e o tratamento de esgoto não é realizado; os níveis de renda são baixos.

Declaraçóes de morador entrevistado permitem concluir que o panorama atual das condiçóes sociais e espaciais deste núcleo são resultado da precariedade com a qual o Núcleo foi instalado (sem infraestrutura básica e com habitaçôes com baixa qualidade) e o cenário de interesse social é reflexo do público para o qual os lotes deste núcleo foram destinados (pessoas que não tinham condiçôes de adquirirem sua residência a partir do mercado imobiliário).

Comparação da renda do núcleo Nossa Senhora de Guadalupe com os níveis municipais, mostram que esta área está abaixo dos valores médios para São Miguel/RN. Em se tratando de renda de assentamentos subnormais do Brasil, o Núcleo Nossa Senhora de Guadalupe também tem índices mais precários que estes, o que mostra a elevada vulnerabilidade a que os habitantes deste ambiente estão submetidos.

Analisando as semelhanças e diferenças existentes entre a área objeto deste estudo e o Núcleo Tôta Barbosa, que foi regularizado à mesma época, nota-se que embora sejam categorizados como AEIS pelo Plano Diretor Participativo de São Miguel/RN, pertençam ao mesmo município e tenham características em comum, como é o caso da existência de quadra poliesportiva, praças, abastecimento de água por carros pipas, ausência de coleta de esgoto e sistema de drenagem, inexistência de sistema de drenagem, presença de energia pública e domiciliar e coleta de lixo; há distinçóes: o Núcleo Urbano Nossa Senhora de Guadalupe é mais vulnerável economicamente e urbanisticamente no quesito área de lote enquanto o Núcleo Urbano Tôta Barbosa possui maior fragilidade em termos de pavimentação.

Dessa forma, constata-se áreas constituídas de forma irregular e com ocupação da população de baixa renda possuem características que as deixam à margem do efetivo direito à cidade, que pode ser melhorado a partir da legalização das terras (o que ocorreu em 2018 nos Núcleos Urbanos Nossa Senhora de Guadalupe e Tôta Barbosa) e de programas associados a melhorias habitacionais e assistência social.

\section{Agradecimentos}

A primeira autora agradece à CAPES - Código de Financiamento 001 - pela bolsa concedida para a realização do curso de Mestrado em Planejamento e Dinâmicas Territoriais no Semiárido (PLANDITES).

\section{Referências}

ARRUDA, S. N.; LUBAMBO, C. W. Entre a cidade informal e a cidade formal: a regularização fundiária como instrumento de inclusão dos invisíveis sociais na Comunidade de Roda de Fogo no Município do Recife. Ciência \& Trópico, Recife, v. 43, n. edição especial, p. 159-184, 2019. 
ATLAS DO DESENVOLVIMENTO HUMANO BRASIL. São Miguel/RN. Disponível em: <http://atlasbrasil.org.br/2013/pt/consulta/>. Acesso em: 04 abr. 2020.

BRASIL. Lei 6.766, de 19 de dezembro de 1979. Dispóe sobre o Parcelamento do Solo Urbano e dá outras Providências. Diário Oficial da República Federativa do Brasil.

BRASIL. Lei 10.257, de 10 de julho de 2001. Regulamenta os arts. 182 e 183 da Constituição Federal, estabelece diretrizes gerais da política urbana e dá outras providências. Diário Oficial da República Federativa do Brasil.

BRASIL. Lei 11.977, de 07 de julho de 2009. Dispóe sobre o Programa Minha Casa, Minha Vida - PMCMV e a regularização fundiária de assentamentos localizados em áreas urbanas... Diário Oficial da República Federativa do Brasil.

BRASIL. Lei 13.465, de 11 de julho de 2017. Dispóe sobre a regularização fundiária rural e urbana... Diário Oficial da República Federativa do Brasil.

BRASIL. Decreto 9.310, de 15 de março de 2018. Institui as normas gerais e os procedimentos aplicáveis à Regularização Fundiária Urbana e estabelece os procedimentos para a avaliação e a alienação dos imóveis da União. Diário Oficial da República Federativa do Brasil.

COMPANHIA DE PESQUISA DE RECURSOS MINERAIS (CPRM) - Serviço Geológico do Brasil. Projeto cadastro de fontes de abastecimento por água subterrânea. Diagnóstico do município de São Miguel, estado do Rio Grande do Norte. MASCARENHAS, J. C.; BELTRÃO, B. A.; SOUZA JUNIOR, L. C.; PIRES, S. T. M.; ROCHA, D. E. G. A.; CARVALHO, V. G. D. (orgs.). Recife: CPRM/ PRODEEM, 2005.

DIAS, A. L. N.; CARVALHO, A. W. B.; ALMEIDA FARIA, T. C.; SANTOS, J. M. Análise comparativa dos processos de produção da irregularidade urbana nas áreas centrais e periféricas: o caso de Viçosa, MG. Oikos: Família e Sociedade em Debate, Viçosa, v. 25, n. 1, p. 114-136, 2014.

FERNANDES, E. Regularizaçáo de Assentamentos Informais na América Latina. Cambrige: Lincoln Institute of Land Policy, 2011.

FONTANELLA, B. J. B.; RICAS, J.; TURATO, E. R. Amostragem por saturação em pesquisas qualitativas em saúde: contribuições teóricas. Cadernos de Saúde Pública, Rio de Janeiro, v. 24, n. 1, p. 17-27, 2008.

HARVEY, D. A Produção Capitalista do Espaço. Tradução: Carlos Szlak. São Paulo: Annablume, 2005. 252 p. 
INSTITUTO BRASILEIRO DE GEOGRAFIA E ESTATÍSTICA (IBGE). 1972. Divisão do Brasil em regióes funcionais urbanas. Rio de Janeiro. Disponível em: <https://biblioteca.ibge.gov.br/index.php/biblioteca-catalogo?view=detalhes\& id=213622>. Acesso em: 05 abr. 2020.

INSTITUTO BRASILEIRO DE GEOGRAFIA E ESTATÍSTICA (IBGE). 1987. Regiáo de Influência das Cidades. Rio de Janeiro. Disponível em: <https://biblioteca. ibge.gov.br/index.php/biblioteca-catalogo? view=detalhes $\&$ id=219139>. Acesso em: 05 abr. 2020.

INSTITUTO BRASILEIRO DE GEOGRAFIA E ESTATÍSTICA (IBGE). 2000. Regiaao de Influência das Cidades 1993. Rio de Janeiro. Disponível em: <https:// biblioteca.ibge.gov.br/index.php/biblioteca-catalogo?view=detalhes\&id=27199>. Acesso em: 05 abr. 2020.

INSTITUTO BRASILEIRO DE GEOGRAFIA E ESTATÍSTICA (IBGE). 2008. Regiáo de Influência das Cidades 2007. Rio de Janeiro. Disponível em: <https:// biblioteca.ibge.gov.br/index.php/biblioteca-catalogo?view=detalhes\&id=240677>. Acesso em: 05 abr. 2020.

INSTITUTO BRASILEIRO DE GEOGRAFIA E ESTATÍSTICA (IBGE). 2011. Censo Demográfico 2010 Sáo Miguel. Disponível em: <https://cidades.ibge.gov.br/brasil/rn/ sao-miguel/pesquisa/23/24007?detalhes=true>. Acesso em: 27 out. 2019.

INSTITUTO BRASILEIRO DE GEOGRAFIA E ESTATÍSTICA (IBGE). 2011. Aglomerados Subnormais primeiros resultados. Disponível em: <https://pt.slideshare. net/Aldemirfreire/agsn-apresentao-1>. Acesso em: 27 out. 2019.

INSTITUTO BRASILEIRO DE GEOGRAFIA E ESTATÍSTICA (IBGE). 2011. Domicílios particulares permanentes, por situação do domicílio e existência de banheiro ou sanitário e número de banheiros de uso exclusivo do domicílio, segundo o tipo do domicílio, a condiçáo de ocupação e o tipo de esgotamento sanitário. Disponível em: <https://sidra.ibge.gov.br/Tabela/1394>. Acesso em: 27 out. 2019.

INSTITUTO BRASILEIRO DE GEOGRAFIA E ESTATÍSTICA (IBGE). 2011. Domicílios Particulares Permanentes: Classe de rendimento nominal mensal domiciliar - São Miguel/RN. Disponível em: <https://cidades.ibge.gov.br/brasil/rn/sao-miguel/ pesquisa/23/22787?detalhes=true > . Acesso em: 27 jul. 2018.

INSTITUTO BRASILEIRO DE GEOGRAFIA E ESTATÍSTICA (IBGE). (2011). Domicílios Particulares Permanentes: Classe de rendimento nominal domiciliar per capita - São Miguel/RN. Disponível em: <https://cidades.ibge.gov.br/brasil/rn/saomiguel/pesquisa/23/26170?detalhes=true>. Acesso em: 27 out. 2019. 
INSTITUTO BRASILEIRO DE GEOGRAFIA E ESTATÍSTICA (IBGE). 2013.

Aglomerados Subnormais Informaçóes Territoriais. Disponível em: <https://biblioteca. ibge.gov.br/visualizacao/periodicos/552/cd_2010_agsn_if.pdf>. Acesso em: 27 out. 2019.

INSTITUTO BRASILEIRO DE GEOGRAFIA E ESTATÍSTICA (IBGE). 2017. Sáo Miguel: Panorama. Disponível em: <https://cidades.ibge.gov.br/brasil/rn/sao-miguel/ panorama>. Acesso em: 02 abr. 2020.

INSTITUTO DE PESQUISA ECONÔMICA APLICADA (IPEA). 2016. Relatório brasileiro para o Habitat III. Brasília: ConCidades, IPEA, 2016.

LIMA, D. F; SOUSA JUNIOR, A. M. Socioespacial aspects of social interest area: a case study in the city of São Miguel, Rio Grande do Norte, Brazil. Research, Society and Development, Itabira, v. 9, n. 1, p. 1-32, 2020.

MARICATO, E. Metrópole, legislação e desigualdade. Estudos avançados, São Paulo, v. 17, n. 18, p. 151-166, 2003.

MARICATO, E. Conhecer para resolver a cidade ilegal. In.: L. B. Castriota (org.). Urbanizaçáo brasileira: redescobertas: Belo Horizonte: Arte, 2003. p. 78-96.

MARICATO, E. É a questão urbana, estúpido! In.: VAINER, C.; HARVEY, D.; MARICATO, E.; BRITO, F.; PESCHANSKI, J. A.; MAIOR, J. L. S.; SAKAMOTO, L.; SECCO, L.; IASI, M. L.; NINJA, M.; DAVIS, M.; Movimento Passe Livre; OLIVEIRA, P. R.; ROLNIK, R.; BRAGA, R.; VIANA, S., ŽIŽEK, S.; LIMA, V. A. Lima. Cidades

Rebeldes: Passe livre e as manifestações que tomaram conta do Brasil. São Paulo: Boitempo Editorial, 2013. p. 32-46 (digital).

MINISTÉRIO DAS CIDADES. 2009. Regularização Fundiária Urbana no Brasil. Brasília, 2009. Disponível em: <http:/www.capacidades.gov.br/biblioteca/detalhar/ id/172/titulo/regularizacao--fundiaria-urbana--no-brasil->. Acesso em: 28 fev. 2017.

MINISTÉRIO DAS CIDADES. 2014. Estatuto da Cidade e Regularização Fundiária. Brasília. Disponível em: <http://www.planejamento.gov.br/assuntos/patrimonio-da-uniao/ programa-de-modernizacao/linha-do-tempo/arquivos-e-publicacoes/estatuto-da-cidade-eregularizacao-fundiaria.pdf>. Acesso em: 27 out. 2019.

MORAES, A. F; GOUDARD, B.; OLIVEIRA, R. Reflexóes sobre Cidade, seus Equipamentos Urbanos e a Influência destes na Qualidade de Vida da População. INTERthesis: Revista Internacional Interdisciplinar, Florianópolis, v. 5, n. 2, p. 93103, 2008.

NUNES, M. A. C.; FIGUEIREDO JUNIOR, C. M. A. Regularização Fundiária Urbana: Estudo de Caso do Bairro Nova Conquista, São Mateus - ES. Revista de Direito da Cidade, Rio de Janeiro, v. 10, n. 2, p. 887-916, 2018. 
PENNA, N. A.; FERREIRA, I. B. Desigualdades socioespaciais e áreas de vulnerabilidades nas cidades. Mercator-Revista de Geografia da UFC, Fortaleza, v. 13, n. 3, p. 25-36, 2014.

PROGRAMA ACESSO À TERRA URBANIZADA. Acervo de Dados 2015-2018. Pau dos Ferros/RN, 2018.

PROGRAMA DAS NAÇÓES UNIDAS PARA OS ASSENTAMENTOS HUMANOS (ONU-HABITAT. 2016. Conference on Housing and Sustainable Urban Development (Habitat III). Habitat III thematic meeting on informal settlements. Disponível em: <http://habitat3.org/wp-content/uploads/Pretoria-Declaration-E.pdf>. Acesso em: 06 abr. 2020.

REIS, É. V. B.; OLIVEIRA, M. L. A regularização fundiária urbana e rural: necessidade de marcos teóricos e de políticas públicas distintos. Rev. Bras. Polít. Públicas (Online), Brasília, v. 7, n. 2, p. 41-53, 2017.

SÃO MIGUEL. Lei 656, de 30 de junho de 2008. Dispõe sobre o Plano Diretor Participativo de São Miguel/RN. Disponível em: <https://www.saomiguel.rn.gov.br/ legislacao/leis-municipais>. Acesso em: 27 out. 2019.

SÃO MIGUEL. 2017. Cronologia Histórico-Política e Administrativa de São Miguel. Cartilha 25 p.

SILVA, S. S. D. B.; BEZERRA, J. A. A EXPANSÃO URBANA DE SÃO MIGUEL (RN): PLANEJAMENTO URBANO E CONFORMIDADES EM UMA CIDADE DE PEQUENO PORTE. ACTA GEOGRÁFICA, Boa Vista, v. 12, n. 30, p. 131-149, 2019.

SISTEMA NACIONAL DE INFORMAÇÕES SOBRE SANEAMENTO (SNIS). 2019. Diagnóstico dos Serviços de Água e Esgoto 2017. Disponível em: <http://www.snis.gov. br/diagnostico-agua-e-esgotos/diagnostico-ae-2017>. Acesso em: 04 abr. 2020. 